\title{
Historical ethnopharmacology of the herbalists from Krummhübel in the Sudety Mountains (seventeenth to nineteenth century), Silesia
}

\author{
Krzysztof Spałek', Izabela Spielvogel², Małgorzata Proćków³ ${ }^{3}$ and Jarosław Proćków ${ }^{4^{*}}$ (i)
}

\begin{abstract}
Background: Krummhübel (after 1945, Karpacz) in the Sudety Mountains (now SW Poland) was called "the village of pharmacists". At the end of the seventeenth century, there were 57 households, of which about 40 were inhabited by herbalists. Krummhübel herbalists were the first in the Sudety region who applied medicinal mixtures for the treatment of various diseases (using, among others, plants, oils, minerals and even viper venom) in contrast to previous herbalists who only indicated the use of individual plant species for specific diseases. Riesengebirge (in Polish Karkonosze) potions were sold in Austria, the Czech Republic, Poland and Russia, and some of them could even be purchased in Scandinavia and England. The purpose of this paper is an ethnopharmacological analysis of historical texts of herbalists from Krummhübel. Based on their recipes, we analysed the use reports of drugs. Recently, research on ethnobotany and ethnopharmacological analyses of historical materials or egodocuments related to formulations used in folk medicine have become an important source of acquiring knowledge about new medicines.
\end{abstract}

Methods: Based on 46 recipes of Krummhübel herbalists re-written by Reitzig (1943), we analysed the use reports of drugs which included plant taxa and other constituents such as animal formulations, fungi, inorganic and organic substances and minerals as well as tinctures (with alcohol/spirit) and elixirs (without alcohol/spirit). For each usage mentioned in the text, we recorded (i) the putative botanical identity of the taxon; (ii) the plant family or origin of other than the plant constituent; (iii) the reported plant part; (iv) the number of the recipe; (v) the name of the recipe; (vi) the vernacular name of ingredient; (vii) the described symptom, ailment or specific use; (viii) our modern (viz. biomedical) interpretation of the described symptom or ailment; (ix) the mode of administration; and $(x)$ the category of use under which we filed the specific use. We also cross-checked the medicinal plants of Krummhübel herbalists with the species described in old manuscripts and regional surveys and compared their use with contemporary plant use.

Results: The paper introduces the generated database comprising 348 use reports of 46 drugs based on 70 plant taxa and other constituents. Besides, we address patterns such as the frequent recommendation of Fabaceae herbs for respiratory system issue and gynaecology and Asteraceae for respiratory system and cardiovascular problems. Gastrointestinal use reports are based on Asphodelaceae, Burseraceae and Rosaceae species.

(Continued on next page)

\footnotetext{
* Correspondence: jaroslaw.prockow@upwr.edu.pl

${ }^{4}$ Department of Plant Biology, Institute of Biology, Faculty of Biology and

Animal Science, Wrocław University of Environmental and Life Sciences,

Kożuchowska 5b, 51-631 Wrocław, Poland

Full list of author information is available at the end of the article
}

(c) The Author(s). 2019 Open Access This article is distributed under the terms of the Creative Commons Attribution 4.0 International License (http://creativecommons.org/licenses/by/4.0/), which permits unrestricted use, distribution, and

reproduction in any medium, provided you give appropriate credit to the original author(s) and the source, provide a link to the Creative Commons license, and indicate if changes were made. The Creative Commons Public Domain Dedication waiver (http://creativecommons.org/publicdomain/zero/1.0/) applies to the data made available in this article, unless otherwise stated. 
(Continued from previous page)

Conclusions: Remedies that lost importance over time as well as drugs used for diseases now controlled by conventional medicine may be interesting starting points for research on herbal medicine and drug discovery. It seems to be important to attempt to reproduce therapeutic mixtures from the preserved recipes of Krummhübel herbalists, which offers an opportunity to learn more about the real effects of the former medicines and their therapeutic activity. The obtained data can also be used to search for new drugs.

Keywords: Medicinal plants, Mixtures, Folk medicine, Phytotherapy history, Phytopharmacy, Ethnobotany,

\section{Background}

Caspar Schwenckfeld, a municipal doctor from Hirschberg (after 1945, Jelenia Góra), was one of the first medicinal plant explorers operating in the Silesia region. Two monographs of great value are the result of his scientific work. Chronologically, his scientific work describing resorts in Warmbrunn (after 1945, Cieplice), Landeck (after 1945, Lądek-Zdrój), Flinsberg (after 1945, Świeradów) and Salzbrunn (after 1945, Szczawno) appeared first [1, 2], and 7 years later, another monograph was released. It describes 50 species of plants that were used in phytotherapy at the turn of the seventeenth century in health resorts in the Sudety Mountains (in German, Sudeten), SW Poland, mainly in Warmbrunn [3]. Many species of medicinal plants formerly used in phytopharmacy now have scientifically demonstrated medicinal properties based on their diverse chemical compositions (e.g. [4-8]).

The purpose of the work is an ethnopharmacological analysis of historical texts of the so-called Krummhübel laboratory workers, who were active in the Sudetes (Central Europe) from the seventeenth to nineteenth centuries. Our research will contribute to a better understanding of treatments for diseases in this region prior to the development of the pharmacological industry. It will also provide in-depth insight into old methods of treatment. So far, no research has been carried out on ethnopharmacological activities of the herbalists from Krummhübel. In particular, this study may guide research on novel phyto-therapeutic agents, inform safety evaluations and help to prove the tradition of use in terms of drug regulations $[9,10]$.

We also cross-checked the medicinal plants of Krummhübel herbalists with the species described in five manuscripts and regional surveys, including Matthioli (1563) [11], Schwenckfeld (1607) [3], Mattuschka (1779) [12], Kneipp (1892) [13], Fischer (1930s) [14] and Madaus (1938) [15]. Besides, we compared their uses with those of other contemporary plants.

Recently, research on ethnobotany and ethnopharmacological analysis of historical materials or egodocuments, related to preparations used in folk medicine, has become an important source of acquiring knowledge about new medicines $[10,16]$. Our study may constitute a part of this trend.
Karpacz (formerly Krummhübel) is a town located in Silesia in Poland. Until the mid-sixteenth century, this region belonged to the Kingdom of Bohemia, and in 1526, it became a part of the Habsburg Empire. As a result of the Silesian wars in the years 1740-1742, Silesia came under the rule of the Kingdom of Prussia and remained within the German borders until 1945. After World War II, under the terms of the agreements at the Yalta Conference and the Potsdam Agreement (both in 1945), German Silesia, east of the rivers Oder (now Odra) and Lusatian Neisse (now Nysa Łużycka), was transferred to Poland. This region included Krummhübel (after 1945 renamed Karpacz), the area of the herbalists' activities described in this article $[17,18]$.

The beginnings of the production of herbal medicinal mixtures in the Sudety Mountains are related by multiple sources. One of them speaks of two protestants, well-known medics from Prague, who fled to the town of Krummhübel in the Sudety Mountains in the late seventeenth century to avoid punishment for participation in a bloody duel. Niclaus and Solomon found refuge in the house of Melchior Grossmann, where they established the first pharmacy in Krummhübel and introduced their saviour and his friend Jonas Exner to the art of producing herbal ointments, powders and tinctures [19-24]. At the end of the seventeenth century, Krummhübel had 57 households, of which about 40 were inhabited by herbalists, also known as "Laboranten" (in German). For this reason, Krummhübel was called "the village of pharmacists" [23-30]. The herbalists' houses were log cabins with pitched roofs, timber framing and very distinctive interiors. The largest room on the ground floor, built of granite stones, was a laboratory with a large kitchen oven and distillation equipment (Fig. 1).

In the adjacent room, the medicinal raw material was produced and portioned. A side chamber, where cabinets, barrels, crates and shelves were located, served as a warehouse for storing products, and an airy loft served as a drying room for herbs. The dried products were stored in small free-standing structures due to the danger of fire [23, 31]. Next to the laboratory building, there was a backyard with medicinal plants, where, among others, the following plants were grown: Plantago lanceolata L., Pimpinella anisum L., Menyanthes trifoliata 


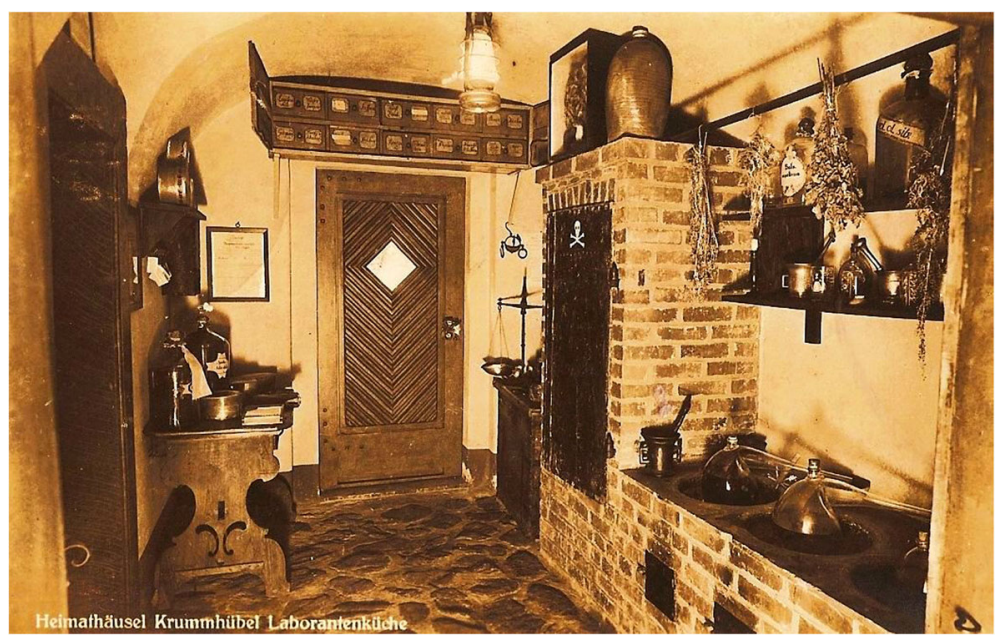

Fig. 1 The museum dedicated to the herbalists from Krummhübel. Postcard from 1938 (collection of K. Spałek)

L., Artemisia absinthium L., Centaurium erythraea Rafn. subsp. erythraea, Verbascum densiflorum Bertol., Carum carvi L., Trigonella foenum-graecum L., Valeriana officinalis L., Achillea millefolium L., Linum usitatissimum L., Alcea rosea L. var. nigra Cav., Taraxacum spp., Calendula officinalis L., Althaea officinalis L., Polygonum aviculare L., Rosa canina L., Ruta graveolens L., Salvia officinalis L. and Thymus pulegioides L. Shrubs were also popular: Viburnum opulus L. and Sambucus nigra L. The most widespread plant, used for the production of many medicines, was Digitalis purpurea L., which still commonly grows on the slopes of the Sudety Mountains $[23,25,32-34]$. The other most popular plants used to manufacture medicaments were Carlina acaulis L., Primula elatior (L.) Hill, Arnica montana L., Lilium martagon L., Rhodiola rosea L. and Crocus sp., i.e. probably $C$. sativus $\mathrm{L}$. There are no voucher specimens associated with this study, so precautions in the identification of plant taxa in old written documents discussed by Łuczaj [35] were taken. Herbalists from Krummhübel enriched many drugs with powder roots of Mandragora officinarum L. [23], a plant species from the Solanaceae family, originating from the Mediterranean area and the Middle East and also grown in Krummhübel [36]. The following raw materials were used in therapeutics of the Mediterranean countries: the root Mandragorae radix and the herb Mandragorae herba, both of which contain tropane alkaloids. The root has anaesthetic and hypnotic properties, while the herb, with a lower content of alkaloids, is used in homoeopathy as a drug of analgesic properties for rheumatic diseases. Mandragora officinarum is one of the plants with the longest history of use in phytotherapy. It has already been mentioned in Egyptian papyri from 3000 years BC $[4,37,38]$. In the Middle Ages, a great cult developed around this plant as a panacea for any disease and a magical agent. At the end of the sixteenth century, the species disappeared from most of the drug stores and were obtained from the official European herbal market [36]. However, herbalists from Krummhübel used it until the end of the seventeenth century [25]. They were also the first in central Europe to use the herb Drosera rotundifolia L.-Droserae herba as a medicinal agent that had already been confirmed by Rittman [25]. Earlier, alchemists had examined the secretions of this plant's glandular hairs that digest insects as they searched for preparations that could produce gold or a youth elixir. It also belonged to the group of so-called sacred herbs. Nowadays, this species is strictly protected by law in Poland, and the material for medicinal use comes from import only. Extracts of Droserae herba include derivatives of naphthoquinone, flavonoids and organic acids, which have antibacterial and antispastic properties $[6,7,39]$. The herbalists from Krummhübel also introduced Rhodiola rosea to phytotherapy in the Sudety region [25]. In medical practice, the rhizome of this species is now used, Rhizoma Rhodiolae, which has stimulating properties and enhances concentration and increases physical activity. It is used to treat tiredness, neurosis and anaemia [5, 39]. For these disorders, it was used in the form of mixtures by the Krummhübel herbalists [25].

To describe medicines, the herbalists used notes, armorials and prescriptions. Latin names were used to protect their trade secrets. Knowledge of Latin was required during the masters exam for herbalists, which was introduced around the year 1700 . It was then that herbalists from Krummhübel and the surrounding area formed the common herbalists' guild, one of the first in Central Europe. Medicinal knowledge was usually kept in secret by family members and passed from one generation to another. In the eighteenth century, Krummhübel herbalists manufactured more than 200 proprietary medicines [22-25, 40]. 
We confirmed that they were the first in the Sudetes who applied medicinal mixtures to the treatment of diseases (using, among others, plants; oils; powdered minerals, including rock crystal and amethyst; and animal formulations-adder venom, deer horns, toads, salamanders and frogs), and they left their medical legacy in writing [23] in contrast to previous herbalists, who only indicated the use of individual plant species for specific diseases. (The first researcher who published data on the distribution of medicinal plants and their therapeutic properties from the described area was the renaissance physicist Caspar Schwenckfeld from Hirschberg. The naturalist, however, did not provide and did not use any medicinal mixtures [1].) Medications from Krummhübel were mixed with water, wine, honey, oils, salts, acids and alcohol distilled in local or domestic distilleries [31, 37]. For instance, the tincture of Arnica montana was used as a painkiller and anti-inflammatory drug against digestive system disorders as well as used externally for bruises, frostbite and open wounds [23].

However, not all of these plants can be found in the recipes that have survived to this day (e.g. Arnica montana, Rhodiola rosea or Mandragora officinarum) [23]. Nevertheless, it was confirmed that specimens of these species so far are stored within the collections of the Museum of Sports and Tourism in Karpacz, and they certainly were used by the herbalists from Krummhübel.

The reign of the House of Hapsburg in Hirschberg brought no restrictions on the herbalists' activities. However, the situation changed after 1740, when the area came under the rule of Prussia. As the popularity of the goods produced by the herbalists of Krummhübel increased, resentment and jealousy of doctors and pharmacists rose as well, since they considered them charlatan family clans who made fortunes from human illnesses [23, 31]. The desire to limit their activities also resulted from the Prussian administration's wish to organise, e.g. health care, on a national level. The office of the Collegium Medicum et Sanitatis (Royal Council of Physicians and Pharmacists) intervened to limit the activity of the herbalists, and the production of herbal medicines by so-called laboratory workers was then only possible with an official license, and not based on the rules of the guild. The Act of 1740, issued by the Prussian government, reduced the number of legally operating herbalists to 30 persons only. To obtain a license, one had to wait for the death of a guild member and go through a long official procedure. In 1796, the herbalists' guild comprised 27 members [23, 24]. The leaders of the guild were Christian Ignatius Exner (guild master), Benjamin Gottlieb Exner (guild chief) and Johannes Christoph Grossmann (guild chief assistant). The oldest known book by Krummhübel herbalists was produced in 1792 [22-25] and contained 150 recipes for mixtures made from local medicinal plants. From the late eighteenth century onwards, the herbalists encountered more and more difficulties. In 1796, the Prussian government allowed them to produce and sell only 46 medicines [23, 24]. Junker [24] provides a full list of them: (1) Aqua apoplectica alba s. pauperum, weißes Schlagwasser; (2) Aqua apoplectica rubra, rotes Schlagwasser; (3) Balsamus anglicus, englischer Haupt- und Universalbalsam; (4) Balsamus embryonum liquidus, stärkender Kinderbalsam; (5) Balsamus sulpburis; (6) Balsamus vitae, Lebensbalsam; (7) Elixir pectorale; (8) Elixir proprietatis Paracelsi; (9) Elixir vitrioli Mynsichti; (10) Elixir uterinum; (11) Essentia absynthii composita; (12) Essentia alexipharmaca; (13) Essentia amara; (14) Essentia antidysenterica, Ruhrtropfen; (15) Essentia carminativa; (16) Essentia castorei; (17) Essentia corticum aurantiorum; (18) Essentia dulcis; (19) Essentia lignorum; (20) Essentia myrrhae; (21) Essentia rhei amara; (22) Essentia stomacbica composita, stärkende Gall- und Magentropfen; (23) Essentia succini; (24) Essentia absynthii simplex; (25) Liquor anodynus mineralis Hofmanni; (26) Mixtura symplex; (27) Morsuli anthelmintici; (28) Pulvis anthelminticus; (29) Pulvis bezoardicus; (30) Pulvis dentifriticus, Zahnpulver; (31) Pulvis marchionis, Marggrafenpulver; (32) Pulvis sternutatorius viridis, Hauptpulver; (33) Pulvis vitae; (34) Species zum Brust- und Blutreinigungsthee; (35) Spiritus соти cervi; (36) Spiritus matricalis; (37) Spiritus melissae compositus; (38) Spiritus nitri dulcis; (39) Spiritus salis ammoniaci aromatica; (40) Spiritus salis ammoniaci volatilis; (41) Spiritus tartari; (42) Spiritus theriacalis; (43) Tinctura bezoardica; (44) Tinctura coralliorum; (45) Tinctura laxans; and (46) Tinctura antimonii tartarisata.

All 46 known recipes were provided by Reitzig [23], because he was studying the original manuscripts and recipes of the herbalists from Krummhübel, located in the then pre-war museum [41]. These manuscripts have not survived-they were lost in the war turmoil, which was confirmed directly by the Museum of Sports and Tourism in Karpacz and by the local libraries.

In 1797, licensed pharmacists persuaded the Prussian government to withdraw the privilege of selling the so-called drop of Krummhübel at fairs; it was one of the best-known medicines produced by the herbalists [31, 37]. In 1799, information was provided about a complementary treatment in the Warmbrunn spa by an anonymous relation of the practitioner. A herbalist with the initials P.I. was described, and during his presence at the spa, he was offering medicinal herbal mixtures to patients on request [23].

Despite the growing administrative difficulties, the popularity of medications from Krummhübel continued to increase. Among others, the eminent writer and representative of German Romanticism, Johann Wolfgang 
von Goethe, took an interest in medicinal herbs [42, 43]. Riesengebirge (in Polish Karkonosze, in the Western Sudetes) potions were sold in Austria, the Czech Republic, Poland and Russia, and at the turn of the nineteenth century, some of them could also be purchased in Scandinavia and England. In 1810, in the Sudetes, a company named W. Koerner \& Co. was founded, which specialised in the production of liqueurs and tinctures prepared from Sudetic herbs [23, 24]. In subsequent years, the pharmacist herbalists of Krummhübel were affected by further restrictions. They were suspected of practicing black magic, secret cults, alchemy and possessing devil's knowledge. In 1809, the authorities of Legnica Province (in German Kreis Liegnitz) banned the herbalists from conducting door-to-door trade. In the period from 1831 to 1832, a cholera epidemic raged in Central Europe, also reaching the Sudetes [31]. Fears of the disease were so great that the government decided to reach out for help from the Krummhübel herbalists. Carl Traugott Ende, who came from a family with a long tradition of herbalists, prepared medications for patients and was a member of the anti-cholera epidemic committee [23]. Despite this, the administrative restrictions on herbalists were restored after the end of the plague [42, 43]. In 1843, a royal edict was issued to limit the allowable number of simple Riesengebirge (Karkonosze) herbal medicines from 46 to 21 . The list of 21 medicinal preparations approved in 1845 by the district doctor Dr. Schaeffer is as follows [23]: (1) Aqua apoplectica alba s. pauperum; (2) Aqua apoplectica rubra (Schlagwasser); (3) Balsamum anglicus, englischer Haupt- und Universalbalsam; (4) Balsamum vitae, Lebensbalsam; (5) Elixir pektorale, brustelixir; (6) Essentia amara; (7) Essentia carminativa; (8) Essentia corticum aurantiorum; (9) Essentia dulcis; (10) Essentia lignorum; (11) Essentia rhei Amara, bittere Rhabarber Tinktur; (12) Essentia stomacbica composita, stärkende Gallund Magentropfen; (13) Liquor anodynus, mineralis Hoffmanni Hoffmannsche Tropfen; (14) Pulvis sternutatorius viridis, Hauptpulver; (15) Pulvis Vita, Lebenspulver; (16) Species pectorales, Brust- und Blutreinigungsthee; (17) Spiritus melissae compositus, Karmelitenwasser; (18) Spiritus salis ammoniaci, aromaticus sive Spirit. volatilis oleosus Sylvii; (19) Spiritus salis ammoniaci volatilis; (20) Spiritus nitri dulcis; and (21) Tinctura Coralliorum, Corallen Tinktur.

For the preparation of medicaments, only 24 strictly specified types of fruits and barks, 20 types of roots, 16 species of herbs (= aerial parts), 10 seeds and flowers and 2 species of timber were allowed [23]. In 1843, the Prussian government stopped issuing new licenses for herbal practices, which was the beginning of the end of the herbalists' activity. In the Riesengebirge (Karkonosze), the herbalists' art began to fade away in the second half of the nineteenth century. It was still possible to find some isolated cases of treatment using local herbs in later years, albeit only on a small scale. The last herbalist of the herbalists' guild died on 28 March 1884 [23, 44].

The heritage of the herbalists from Krummhübel, regarding the use of medicinal plants and their mixtures, remained, mainly in the Sudety Mountains, until the beginning of the twentieth century, especially in folk medicine. Drosera rotundifolia may be presented as an example. It was used in the form of infusions for poor digestion, whooping cough and sclerosis by the residents of the Masyw Ślęży Mountains (in German Zobten-Gebirge) until the beginning of the twentieth century, although the species has not been found in the area so far [45].

The good reputation of Krummhübel herbalists and their gardens with medicinal plants is evidenced by the fact that they were visited by famous German botanists, including Max von Uechtritz [46].

Research on the activities of herbalists of Krummhübel was conducted by Will Erich Peuckert (18951969), a world-famous German ethnographer and ethnologist. In 1934, Peuckert became a professor at the Universität Breslau (University of Wrocław) and created a museum dedicated to the Krummhübel herbalists [23], which was, however, closed in the 1950s. Nowadays, an exhibition on pharmacist workers, including numerous exhibits, is held by the Museum of Sports and Tourism in Karpacz, which is the successor of the pre-war museum $[47,48]$.

\section{Material and methods}

Based on 46 recipes by Krummhübel herbalists, re-written by Reitzig [23], we performed the analysis of use reports of drugs, which included plant taxa and other constituents such as animal formulations, fungi, inorganic and organic substances, minerals and tinctures (with alcohol/spirit) and elixirs (without alcohol/spirit). For each usage mentioned in the text, we recorded (i) the putative botanical identity of the taxon; (ii) the plant family or origin of other than the plant constituent; (iii) the reported plant part; (iv) the number of the recipe; (v) the name of the recipe; (vi) the vernacular name of the ingredient; (vii) the described symptom, ailment or specific use; (viii) our modern (viz. biomedical) interpretation of the described symptom or ailment; (ix) the mode of administration; and $(x)$ the category of use under which we filed the specific use. Each recorded combination of the variables was counted as one individual (therapeutic) use report.

The following 10 plant parts or products were differentiated: barks, exudates (incl. gums, resins and saps), flowers (incl. inflorescences and parts thereof), fruits (incl. parts thereof), herbs (= aerial parts, incl. branches and shoots), leaves, oils (e.g. linseed oil), seeds, 
subterranean parts (incl. bulbs, rhizomes, roots and tubers) and wood. If there was no information on which plant part was used, it was qualified as an herb. The modes of administration were divided into two groups: internal (e.g. drops, many tinctures) and external (e.g. ointments and poultices). Use reports were classified into organ-, symptom- and ailment-defined categories of use, largely following the bioprospecting-oriented classification scheme proposed by Staub et al. [10]. The applied 15 categories of use citations comprise the following: andrology (incl. male fertility and venereal diseases: gonorrhoea, syphilis), antidotes (internally applied), cardiovascular problems, dermatology (e.g. tumours, injuries and wounds), fever, gastroenterology (e.g. appetite, intestinal obstruction, lithiasis liver and tympanites), gynaecology (incl. female fertility and venereal diseases: gonorrhoea, syphilis), musculoskeletal ailments (e.g. cramps, gout, rheumatism, scurvy and spasms), neurology (incl. psychosomatic ailments), oral cavity (e.g. dentistry and stomatitis), others ("internal wounds" and "for breast" but others than connected with respiratory system), parasites (e.g. anthelmintics), respiratory system (e.g. cleansing lungs and the upper respiratory tract, plague, tuberculosis) and urology (e.g. diuretics, lithiasis and kidneys).

This work also aimed at recalling the activities of Krummhübel herbalists and their input into the medical use reports of plants at that time. Taking this into account, we present selected species of medicinal plants and mixtures used by them, based on their recorded recipes. We selected the plant species that were most often used in mixtures and which were simultaneously growing in the medicinal plant gardens of Krummhübel herbalists. To achieve all these goals, we translated available source texts, including books, articles from magazines and guides as well as press notes on the activity of Krummhübel herbalists, from German.

We compared the medicinal plants of Krummhübel herbalists with the medicinal plant lists of Europe by cross-checking the species used in manuscripts and regional surveys, including Matthioli [11], Schwenckfeld [3], Mattuschka [12], Kneipp [13], Fischer (1930s) [14] and Madaus [15]. Matthioli's book [11] is one of the most popular ethnobotanical studies and describes medicinal species; it was translated into a few languages. Schwenckfeld's publication [3] constitutes the fullest analysis of therapeutic properties of the warm springs in Warmbrunn (Cieplice) as well as the plants used in spa and healing treatments [49]. Mattuschka is known for the work on the natural history of plants native to Silesia, in which he indicates species with medicinal properties [12]. Kneipp, one of the founders of the naturopathic medicine movement, developed his "Nature Cure" form of therapy based on subalpine plants from the Allgäu in Bavaria, which were used in folk medicine, and based on those, he cultivated in the garden [50, 51]. Fischer's data (1930s) comprise the most complete information on folk botany, with nearly 250 plant species, used in the folk culture in the whole area of pre-World War II, Poland, which also includes the present Western Ukraine and parts of Belarus and Lithuania [14]. In his book, a German medical doctor, Madaus [15], discusses homoeopathic products and their use as therapeutic agents.

The paper follows the newest guidance referring to the analysis of historical texts [52]. Plant identifications were established by cross-checking the names and descriptions in the Flora Europaea [53] with the confirmed data that the individual species were growing in the area at that time $[32,33]$ or/and were cultivated in Krummhübel herbalists gardens [46] or/and are stored within the collections of the Museum of Sports and Tourism in Karpacz; thus, they certainly were used by the Krummhübel herbalists. Species names were checked against The Plant List 1.1 [54], and family names follow the Angiosperm Phylogeny Group IV [55].

\section{Results}

\section{Patterns of the diversity of drugs}

In total, among 46 drugs, 70 plant taxa were recorded. Of these, 52 taxa, included in 29 drugs, could be identified to the species and 18 taxa in 13 drugs were identified to the genus level. For 3 ingredients of plant origin, which were included in 5 drugs, no taxa identification was possible. Besides herbal, other constituents were used, including animal formulations (e.g. castoreum, corals, deer antlers, earthworms, scorpions, snakes), fungi, inorganic and organic substances (e.g. calcium, Sp[iritus] Vitrioli, Sp. Nitri dulcis, Sp. Nitri, Sp. Tartari, wax) and minerals (e.g. potash, pumice, salt) as well as elixirs and tinctures. These components were exclusively used in 13 drugs.

Overall, 348 use reports (i.e. unique combinations of a specific taxon or another origin of a constituent, plant part, route of administration and specific use in individual recipes) were recorded. Internal applications, mainly as drops in tea or water (283 use reports), prevail over external applications such as ointments or poultices (69 use reports) (Fig. 2). Seventy-four records have no reported uses, i.e. when Reitzig's [23] original did not clearly state the ailment they were used. The same remark applies to the lacking mode of administration (61 records). A full dataset of the recorded plant taxa, plant parts and other constituents used, as well as the therapeutic uses, is presented in Additional file 1: Table S2 and at the end of this paper.

More than $45 \%$ of drugs stemmed from herbs (= aerial parts) (118), while the remaining percentage consisted of exudates (41), subterranean organs (29), flowers (25) and 


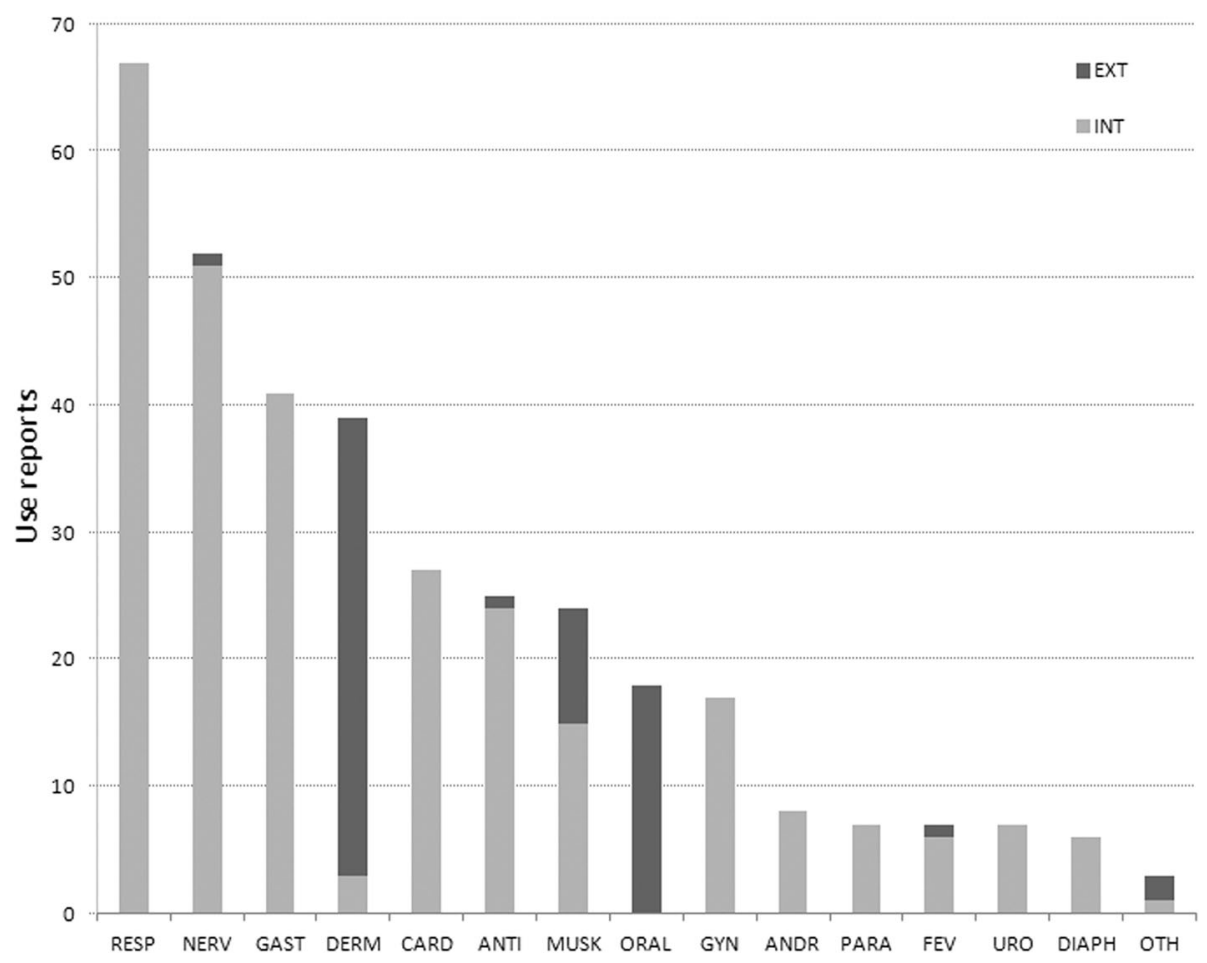

Fig. 2 Number of use reports by category of use and mode of administration $(N=348)$. ANDR, andrology; ANTI, antidotes; CARD, cardiovascular problems; DERM, dermatology; DIAPH, diaphoretic; FEV, fever; GAST, gastroenterology; GYN, gynaecology; MUSK, musculoskeletal ailments; NERV, neurology; ORAL, oral cavity; OTH, others; PARA, parasites; RESP, respiratory system; URO, urology

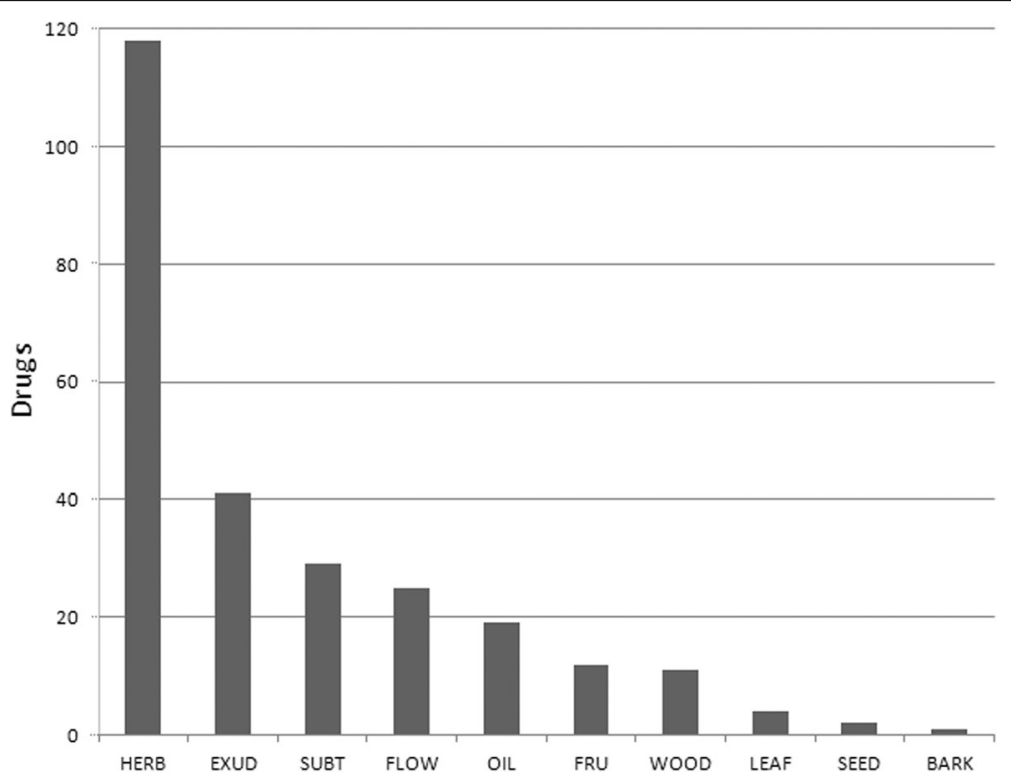

Fig. 3 Number of drugs by plant part ( $N=262)$. BARK, barks; EXUD, exudates; FLOW, flowers; FRU, fruits; HERB, herbs (= aerial parts); LEAF, leaves; OIL, oils; SEED, seeds; SUBT, subterranean parts; WOOD, wood 
other less frequent plant parts (Fig. 3). The drugs were derived from members of 32 vascular plant families, with Asteraceae (9 taxa; 22 drugs), Fabaceae (8 taxa; 33 drugs) and Apiaceae ( 7 taxa; 26 drugs) being the most frequent ones.

To characterise the therapeutic preferences, the associations between taxonomy, plant part or other constituent origins and categories of use were analysed (Figs. 4 and 5). The most frequently cited constituents were those obtained from animals and minerals. Animal formulations were recommended for neurology (12), gynaecology (4) and fever (4), while minerals were suggested for musculoskeletal ailments (7), oral cavity (6), neurology (5) and dermatology (5). Among the plant families, Fabaceae species were relatively frequently cited for respiratory system (10) and gynaecology (4), as well as Asteraceae for respiratory system (10) and cardiovascular problems (5).

The use citations for respiratory system issues are the most frequent ones (67; Fig. 2) and cover ailments concerning the lungs (21) and the upper respiratory tract

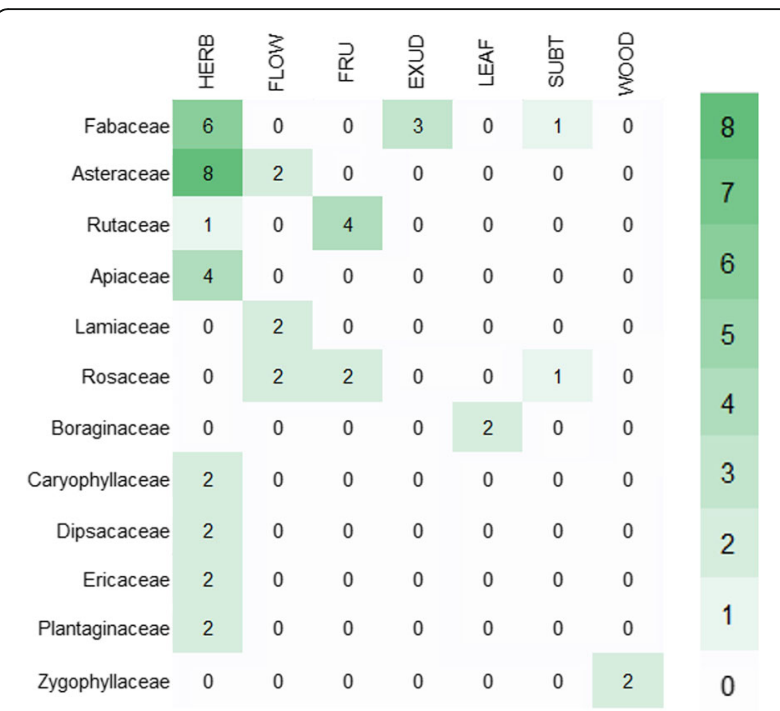

Fig. 5 Quantification of use reports in the categories of respiratory system by plant part and botanical family. Plant part abbreviations follow the legend of Fig. 3

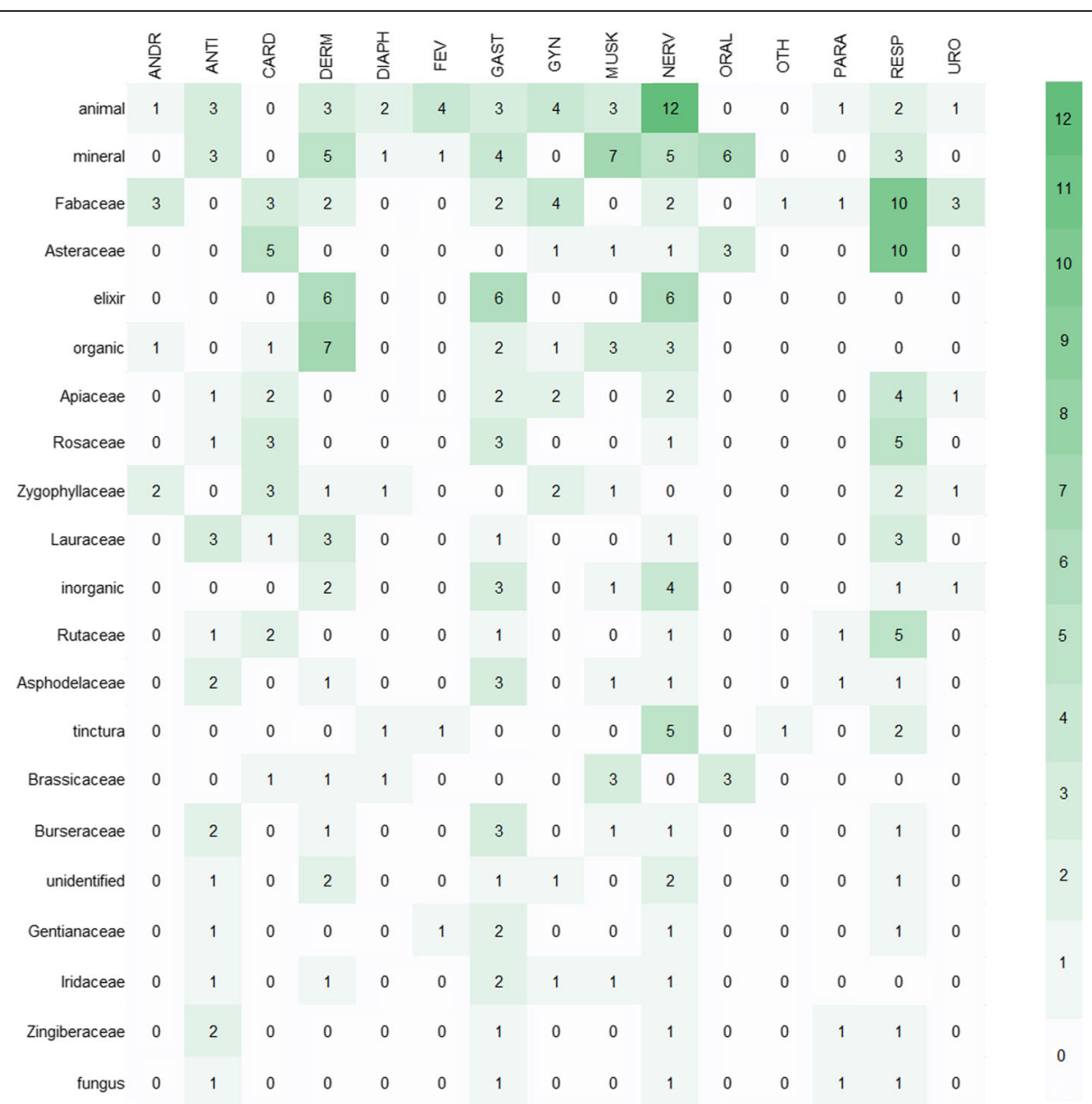

Fig. 4 Quantification of use reports by category of use and the most important botanical families or other constituent origins. The categories of use are abbreviated following the legend of Fig. 2 
(21) as well as plague (17). The remedies for these conditions are taxonomically diverse, including 7 different drugs derived from 34 plant taxa. Herbs of the families Asteraceae and Fabaceae account for a comparably high number of use reports in this category ( 8 and 6, respectively; Fig. 5) and include Achillea spp., Cyanus segetum Hill. (= Centaurea cyanus L.), Matricaria spp., Glycyrrhiza glabra L., Hedysarum spp. and Ononis spinosa L.

The category of nervous system and psychosomatic disorders (52; Fig. 2) includes plague (17), stroke (9), pain of the body (5), headache (3), brain disease (3) or postpartum discomfort (3). The most frequently used constituents were those not obtained from plants, but from animals (12), or were elixirs (6) and minerals (5).

Gastrointestinal use reports (41; Fig. 2) mainly comprise stomach and intestine problems (29) but also refer to appetite (9). Apart from the prevalence of elixirs (6) and minerals (4) in drugs, some use citations are based on Asphodelaceae (3), Burseraceae (3) and Rosaceae (3) species such as Aloë spp., Commiphora spp., Potentilla erecta (L.) Räusch. and Rosa spp.

Dermatology is the fourth largest category of use reports (39; Fig. 2) and mainly covers injuries and wounds
(19) as well as applications for cleaning the head (5) and drying out feet (5). Organic substances (7) and elixirs (6) were the most frequently mentioned drugs. Among the plant families, Lauraceae oils (3) and Oleaceae exudates (3), including species such as Cinnamomum camphora (L.) J. Presl and Olea europaea L., were mostly recommended for uses.

The drugs mentioned for cardiovascular problems (6) are mainly remedies for blood purification (3), while 2 are recommended against oedema (i.e. wood of Guaiacum officinale L. and Sp. Tartari (= Weinstein-Geist)) and flowers of Rosa spp. as a heart tonic.

\section{Sample recipes and plant species}

The extract of Gentiana lutea L.-Essentia Gentianae was recommended in the absence of appetite and for stomach pains. This plant was confirmed to be cultivated by the Krummhübel herbalists in their pharmaceutical gardens [46]. The original recipe was as follows: "Nimm 2 Loth gröblich gestossene Enzian-Wurzel, 1 Qv. starken Branntwein, halte es in der Wärme bis es sich gefärbet, hernach seige sie durch grau Pappier-Dienet in Schwachheit des Magens, bey allen 3 und 4 tägigten

bleibt das A. Cornu Cervi in der FiltrierTüthe, thue den Sp. in einen Kolben, zeuch solchen herüber, so bast du den Sp.C.C. rectificat.

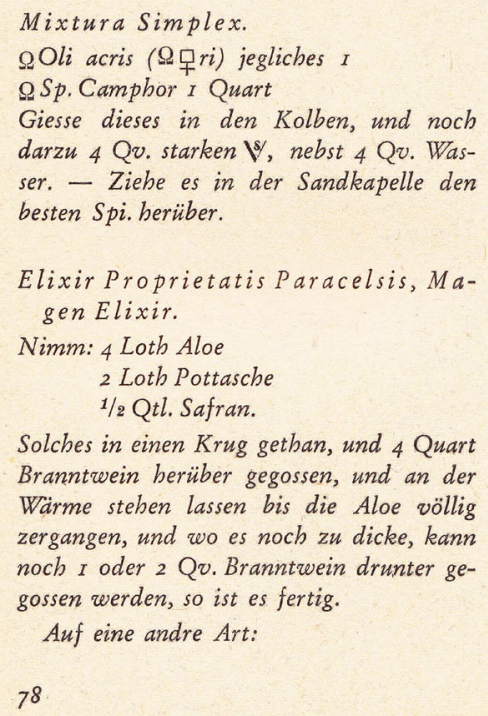

Nimm: 4 Loth Aloes

2 Loth Myrrhen

I Qtl. Safran

2 Loth Pottasche.

Diese Species in einen Krug gethan, und 4 Qv. ̈̈bergezogenen Branntwein drüber gegossen, und in der Wärme stehen lassen bis es dicke genung worden, hernach darvon abgegossen, so ist es fertig. Es dienet dieses Elixir vor einen verdorbenen Magen, macht Appetit zum Essen, führet die Unreinigkeiten ab. Wovon 30, 40, 50 bis 60 Tropfen können gebraucht werden. Aeusserlich ist es gut zum Heilen in allen Schäden.

Elixir Vitrioli Mynsichti.

Nimm: I Dreyer Flasche Corallorum

I Pfund Ess. Carminativae Wedelii

I Glas Ess. Pectoralis

1/2 Pfund roth. Schlagreasser

$1 / 4$ Pfund Sp. Vitrioli.

Dieses alles zusammen in eine 2 Quartige Flasche gegossen, wobl untereinander gemischt, hernach durch gran Pappier laufen

Fig. 6 Original recipe using saffron (bottom part of page 78 and top part of page 79, from Reitzig [23]). Abbreviations: 1 Loth—about one large spoon (in Prussia, this equalled $14.606 \mathrm{~g}$ ); 1 Quintl._1/4 of Loth, which was about 3.651 g; Qv._-250 ml. [Elixir Proprietatis Paracelsis, stomach elixir-take 4 spoons of aloe (Aloë vera (L.) Burm.f.), 2 spoons of potash, $1 / 8$ spoon of saffron (Crocus probably sativus). Put it in a pitcher and pour 4 quarts [ $4 \times 1.14504 \mathrm{l}$ ] of strong spirit, then leave it in a warm place until aloe will completely dissolve, or, if it is still visible, you can add $250 \mathrm{ml}$ or $500 \mathrm{ml}$ of strong spirit until it is ready [i.e. well dissolved]. In a different way: take 4 spoons of aloe, 2 spoons of myrrh, 1/4 spoon of saffron and 2 spoons of potash. Put these species in a pitcher and add $1 \mathrm{I}$ of strong spirit; leave it in a warm place until it is thick enough and pour off when ready. This elixir is served against stomach problems, increases appetite and detoxifies the body. You can take it starting from 30, 40, 50 up to 60 drops. Externally, it is good for healing any injuries.] 
Fiebern 30 bis 40 Tropfen gebraucht" ([23]; explanation of abbreviations in the caption of Fig. 6) [Take 2 spoons of coarsely minced [great yellow] gentian root (Gentiana lutea), $250 \mathrm{ml}$ of strong spirit, and keep it in a warm place until it is dyed; afterwards, seep it through grey paper-serve it in weakness of the stomach, using 30 to 40 drops on all 3 and 4 days of fever.]

An extract from Crocus (probably) sativus was used by Riesengebirge (Karkonosze) herbalists as a spice and a dye (saffron). The extract also helped against digestive system diseases and circulatory problems. When dosed appropriately, it was considered an aphrodisiac and even a hallucination-inducing agent. Some quantitative recipes for this plant are also preserved (Fig. 6, from Reitzig [23]).

A tincture made from the root of Carlina acaulis (a common plant in the area), recommended for digestion, was also appreciated for its antibacterial and antipyretic properties (Fig. 7). Sulphuric acid, manufactured in the Sudetes until the early nineteenth century, was of great importance to the production of herbal potions [22-25]. In the valley of the Kamienna river, there was a facility that produced sulphuric acid from pyrite shale. The term "vitriol" was the essence of the alchemical formulas, contained in the motto: visita interiorem terrae rectificando invenies operae lapidem (i.e. descend into the belly of the Earth, and in distilling you will find the stone of the work) [38, 56].

\section{Discussion}

By using a systematic data extraction technique, we elucidated several salient therapeutic patterns in preserved recipes of Krummhübel herbalists. These include the importance of Fabaceae plants for respiratory system diseases and gynaecology, as well as Asteraceae for respiratory system and cardiovascular problems. Generally, the use citations for respiratory system issues are the most frequent ones and cover ailments concerning the lungs and the upper respiratory tract as well as plague. The remedies for these conditions are taxonomically diverse, including 7 different drugs derived from 34 plant taxa. Gastrointestinal use reports mainly comprise stomach and intestine problems but also refer to appetite and are based on Asphodelaceae, Burseraceae and Rosaceae species. Moreover, animal formulations were recommended for neurology, gynaecology and fever, while minerals were suggested for musculoskeletal ailments, oral cavity, neurology and dermatology.

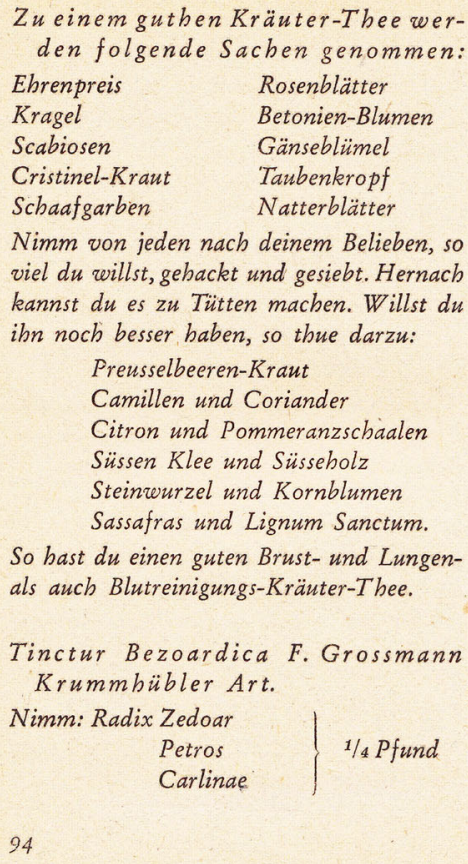

Serpentariae Diptam alb. 1/4 Pfund Imperat

Zerschneide alles miteinander, geuss $4 \mathrm{Qv}$. Sp. Vini und 2 Quart Wasser drauf, zeuch es durch den Destillir-Topf, wenn du merkst, daß der Sp. berüber, so nimm ibn weg und schneide vor 2 Grs, rothen Sandel dazu, und thue $1 / 2$ Loth Campher hinein, so ist sie fertig und bereit.

Tinctur Lunae. Tinktur von Silber. Nimm zart gefeilt oder kapelliert Silber oder geschlagen Silber so viel ibr wollt. Reibet es auf einem Reibstein oder in einer Glasschaale wobl ab, mischet drunter $\Theta U r i-$ nae vol. bis es ein blaulicht Pulver giebt, giesst darüber in einer woblverwabrten Phiole $\Omega$ Ec mit Sp. Vini so viel als nötig, und zieht eine Himmelblaue $R$ beraus. Sie dienet in Haupt-Krankbeiten und ist sonderlich in bösen Wesen vortrefflich gut.

Sp. Tartari. Weinstein-Geist.

Nimm 8 Pfund gemeinen Weinstein, diesen thue in einen Krug oder Retorten, verlutire

95

Fig. 7 Original recipe using Carlina acaulis (bottom part of page 94 and top part of page 95, from Reitzig [23]). Abbreviations: 1 Loth—about 1 large spoon (in Prussia, this equalled 14.606 g); Qv.—250 ml; Grs.—gram [g]. [Tinctur Bezoardica of F. Grossmann in the way of Krummhübel—take Zedoary root (white turmeric, Zedoariae radix, Curcuma zedoaria (Christm.) Roscoe), parsley root (Petros [elini] radix, Petroselinum crispum (Mill.) Fuss), stemless carline thistle root (Carlinae radix, Carlina acaulis) —all together $125 \mathrm{~g}$, as well as black cohosh root (Serpentariae radix, Actaea racemosa L. = Cimicifuga racemosa (L) Nutt), burning bush root (Dictamni albus radix, Dictamnus albus L), masterwort root (Imperat [oriae] radix, Peucedanum ostruthium (L.) W.DJ. Koch = Imperatoria ostruthium L.) —all together $125 \mathrm{~g}$. Chop everything together, add 1 I of Spiritus vini and 2.273 I of water, then pass it through the distiller glass. When the spirit has evaporated, the distillation can be finished and $2 \mathrm{~g}$ of sliced red sandal wood with half a spoon of camphor can be added. It is ready to use.] 
This confirms that medicinal plants were commonly used in ethnomedicine for centuries, because they were the only drugs available to residents of many regions. Knowledge about their healing properties was passed down orally from generation to generation [57]. The past importance of mountain species and the frequent uses against envenomations and intoxications mirror the closer interaction of past societies with their biological environment and different ecological, epidemiological and hygienic conditions.

In the fifteenth century, the first herbaria and also herbals, written by doctors or other professionals, began to appear in Europe [57]. These items, however, do not take into account knowledge about medicinal plant mixtures provided by folk therapists. The phenomenon of herbalists from Krummhübel is connected with the fact that these unprofessional therapists left their knowledge on plant mixtures in a written form to be used for centuries in traditional folk medicine in the Sudety region.

The history of herbalists from Krummhübel shows that historical events, in this case, the disappearance of a well-established knowledge, has a lot to teach us now, such as regulations and restrictions kill traditions, which can also happen nowadays. An example may be the Kneipp phytotherapy method, recognised and currently used in health resort treatments. This method was known in the folk medicine of the Allgäu region in Southern Germany, and in the nineteenth century, it was not allowed as a therapy for a relatively long time (e.g. [58-61]).

The systematic analysis of herbal texts offers unique insights into past herbal medicine [10]. Thus, we also confirm the suggestion of Staub et al. [10] that those drugs with discontinued use might represent interesting starting points for drug discovery and the evaluation of old herbal medicine, especially that the information on this subject was strictly protected and included in the professional secrecy of the Krummhübel herbalists' guild, not available to outsiders for centuries.

\section{Medicinal plants of Krummhübel herbalists used in other ethnobotanical studies}

The highest share of the flora documented as medicinal plants by Krummhübel herbalists was recorded in Madaus [15] and Matthioli [11] and constituted 76.4 and $66.7 \%$, respectively. This indicates that many plants used in medical treatment by Krummhübel herbalists were also known in other regions and in different periods. The medicinal plants, documented in all publications considered, included Angelica spp., Carlina acaulis L., Gentiana spp., Juniperus spp., Rosa spp. and Veronica spp. (Table 1). All of them are native or indigenous plants occurring in Central Europe. Additionally, Gentiana spp., Juniperus spp. and Rosa spp. were used for medicinal purposes through all other time periods in Switzerland [62]. While Polish inhabitants of the Carpathians, among others, valued Angelica archangelica L. and Carlina acaulis L. [57]. In the contemporary literature, only the use of Veronica officinalis is mentioned, but the use of Veronica chamaedrys and $V$. beccabunga is documented in ethnobotanical studies [62], and different Veronica species were cultivated in local Silesian gardens [46].

On the other hand, in therapeutic mixtures of Krummhübel herbalists, eight taxa were exclusive, including mainly exotic plants such as Copaifera officinalis L., Drimys winteri J.R. Forst. \& G. Forst., Hedysarum spp., Myristica fragrans Houtt., Piper longum L., Silene baccifera (L.) Roth and Syzygium aromaticum (L.) Merr. \& L.M. Perry. Although they originate from various parts of the world, they were quite frequently used in several remedies by Krummhübel herbalists and are still highly important herbs in modern folk medicine. The oleoresin of Copaifera trees has been widely used in Neotropical regions for thousands of years and remains a popular treatment for a variety of ailments [63]. One of the most ancient and valuable spices of the Orient is clove (Syzygium aromaticum (L.) Merr. \& L.M. Perry), which has a wide spectrum of biological activity [64]. The exotic plants used by Krummhübel herbalists may also refer to the scholarly origin of their knowledge. This, and the considerable overlap of the nomenclature with the old herbals, indicates that the recipes might have been originated (even if later modified) from the monastic tradition dating back to at least the sixteenth century $[65,66]$, and they may go back even to antiquity. For example, by producing and marketing drugs to the public, Italian Renaissance nuns both augmented the medical resources available in urban society and acquired roles of public significance beyond the spiritual realm [66](Table 2).

\section{Therapeutic effects of medicinal plants in traditional and modern medicine}

It is estimated that over $50 \%$ of the available drugs are currently somehow derived from medicinal plants [67, 68]. Herbal medicine (phytotherapy) is widely being used across the world on a constantly growing basis. Plant drug application is based on the experiences of traditional medicine or on new scientific research and experimental results, i.e. conventional medicine. Many medicinal plants are applied through self-medication or at the recommendation of a physician or pharmacist [69]. Phytotherapy is among the major "complementary" treatments in current use by doctors and other therapists throughout Europe [70]. Contemporary European use and trade in medicinal and aromatic plants are extensive, with eight countries (Germany, Spain, France, the Netherlands, Italy, the UK, 
Table 1 Medicinal plants listed in Krummhübel herbalist recipes (seventeenth to nineteenth centuries) and their occurrences in manuscripts and regional surveys, including Matthioli [11], Schwenckfeld [3], Mattuschka [12], Kneipp [13], Fischer [14] and Madaus [15]

\begin{tabular}{|c|c|c|c|c|c|c|}
\hline $\begin{array}{l}\text { Krummhübel herbalists, } \\
\text { seventeenth to nineteenth } \\
\text { centuries }\end{array}$ & Matthioli (1563) [11] & $\begin{array}{l}\text { Schwenckfeld (1607) } \\
\text { [3] }\end{array}$ & $\begin{array}{l}\text { Mattuschka (1779) } \\
{[12]^{a}}\end{array}$ & $\begin{array}{l}\text { Kneipp (1892) } \\
{[13]}\end{array}$ & $\begin{array}{l}\text { Fischer (1930's) } \\
{[14]^{b}}\end{array}$ & $\begin{array}{l}\text { Madaus (1938) } \\
{[15]}\end{array}$ \\
\hline Achillea spp. & + (as Ptarmica) & - & $\begin{array}{l}+ \text { (as } A . \\
\text { millefolium, A. } \\
\text { ptarmica) }\end{array}$ & + & $\begin{array}{l}+ \text { (mainly as } A \text {. } \\
\text { millefolium L., rare } \\
\text { A. ptarmica L.) }\end{array}$ & $\begin{array}{l}+ \text { (as A. ptarmica, } \\
\text { A. millefolium* }{ }^{*} \text {. } \\
\text { moschata) }\end{array}$ \\
\hline $\begin{array}{l}\text { Actaea racemosa } \mathrm{L} .= \\
\text { Cimicifuga racemosa Nutt. }\end{array}$ & - & - & - & - & + (as A. spicata L.) & + \\
\hline Aloë spp. & + & + (as Aloes Balsam) & - & + & $\begin{array}{l}+ \text { (as A. succotrina } \\
\text { Lam.) }\end{array}$ & $\begin{array}{l}+(\text { many } \\
\left.\text { species }^{*}\right)\end{array}$ \\
\hline $\begin{array}{l}\text { Anacyclus pyrethrum (L.) } \\
\text { Lag. = Anacyclus } \\
\text { officinarum Hayne }\end{array}$ & - & - & - & - & - & $+^{*}$ \\
\hline Angelica spp. & $\begin{array}{l}+ \text { (as Angelica maior, } \\
\text { A. minor) }\end{array}$ & + (as A. erratica) & + (as A. syluestris) & + & $\begin{array}{l}+ \text { (as } A . \\
\text { archangelica L., A. } \\
\text { sylvestris L.) }\end{array}$ & $\begin{array}{l}+(\text { many } \\
\left.\text { species* }{ }^{*}\right)\end{array}$ \\
\hline Artemisia vulgaris $\mathrm{L}$. & + (as Artemisia) & - & + & + & + & $+^{*}$ \\
\hline Bellis perennis $\mathrm{L}$. & + (as Bellis minor) & $+($ as B. minima $)$ & + & - & + & $+^{*}$ \\
\hline Carlina acaulis L. & $\begin{array}{l}+ \text { (as Chamaeleon } \\
\text { albus) } 261\end{array}$ & + & + & + & + & + \\
\hline $\begin{array}{l}\text { Cinnamomum camphora } \\
\text { (L.) J.Presl }\end{array}$ & + (as camphora) & - & - & - & + & $+^{*}$ \\
\hline $\begin{array}{l}\text { Cinnamomum verum } \\
\text { J.Presl }\end{array}$ & - & - & - & - & + & $\begin{array}{l}+(\text { as } C . \\
\text { zeylanicum }\end{array}$ \\
\hline Citrus $\times$ aurantium $\mathrm{L}$. & + & - & - & - & - & $t^{*}$ \\
\hline Citrus limon (L.) Osbeck & + & - & - & - & - & $\begin{array}{l}+ \text { (as } C . \\
\text { limonum) }\end{array}$ \\
\hline Citrus spp. & + (as Citria malus) & - & - & - & - & $\begin{array}{l}+ \text { (many other } \\
\text { species) }\end{array}$ \\
\hline Cochlearia officinalis $\mathrm{L}$. & - & - & + & + & - & $t^{*}$ \\
\hline Commiphora spp. & - & - & - & - & - & $\begin{array}{l}+ \text { (as } C . \\
\text { abyssinica, C. } \\
\text { mukul, C. myrrha) }\end{array}$ \\
\hline Copaifera officinalis L. & - & - & - & - & - & - \\
\hline Coriandrum sativum L. & + (as Coriandrum) & - & - & - & - & + \\
\hline Crocus (probably) sativus $\mathrm{L}$. & + (as Crocus florens) & - & - & - & + & - \\
\hline $\begin{array}{l}\text { Curcuma zedoaria } \\
\text { (Christm.) Roscoe }\end{array}$ & + & - & - & - & - & $+^{*}$ \\
\hline $\begin{array}{l}\text { Cyanus segetum Hill. = } \\
\text { Centaurea cyanus L. }\end{array}$ & + (as Cyanus minor) & - & + & - & - & $+^{*}$ \\
\hline Dictamnus albus L. & + & - & - & - & - & + \\
\hline Dorstenia contrajerva L. & - & - & - & - & + & - \\
\hline $\begin{array}{l}\text { Drimys winteri J.R. Forst. \& } \\
\text { G. Forst. }\end{array}$ & - & - & - & - & - & - \\
\hline Echium vulgare $\mathrm{L}$. & + (as Echium) & - & - & - & - & - \\
\hline $\begin{array}{l}\text { Elettaria cardamomum (L.) } \\
\text { Maton }\end{array}$ & $\begin{array}{l}+ \text { (as } C \text {. minus, } C . \\
\text { medium, C. maius) }\end{array}$ & - & - & - & - & + \\
\hline Ferula assa-foetida $\mathrm{L}$. & $\begin{array}{l}+ \text { (as Ferula }= \\
\text { Nathex })\end{array}$ & - & - & - & - & $+^{*}$ \\
\hline Foeniculum vulgare Mill. & + (as Foeniculum) & - & - & + & + & $+^{*}$ \\
\hline Gentiana spp. & $\begin{array}{l}\text { + (as Gentiana minor } \\
\text { = cruciata, Gentiana }\end{array}$ & $\begin{array}{l}\text { + (as G. major } \\
\text { coeruleo flore, G. }\end{array}$ & $\begin{array}{l}\text { + (as G. lutea, G. } \\
\text { centaurium, } G \text {. }\end{array}$ & + & + & $\begin{array}{l}+(\text { many } \\
\left.\text { species }^{*}\right)\end{array}$ \\
\hline
\end{tabular}


Table 1 Medicinal plants listed in Krummhübel herbalist recipes (seventeenth to nineteenth centuries) and their occurrences in manuscripts and regional surveys, including Matthioli [11], Schwenckfeld [3], Mattuschka [12], Kneipp [13], Fischer [14] and Madaus [15] (Continued)

\begin{tabular}{|c|c|c|c|c|c|c|}
\hline $\begin{array}{l}\text { Krummhübel herbalists, } \\
\text { seventeenth to nineteenth } \\
\text { centuries }\end{array}$ & Matthioli (1563) [11] & $\begin{array}{l}\text { Schwenckfeld (1607) } \\
\text { [3] }\end{array}$ & $\begin{array}{l}\text { Mattuschka (1779) } \\
{[12]^{\mathrm{a}}}\end{array}$ & $\begin{array}{l}\text { Kneipp (1892) } \\
\text { [13] }\end{array}$ & $\begin{array}{l}\text { Fischer (1930's) } \\
{[14]^{\mathrm{b}}}\end{array}$ & $\begin{array}{l}\text { Madaus (1938) } \\
{[15]}\end{array}$ \\
\hline & (probably lutea)) & minor punctato flore) & amarella) & & & \\
\hline Glycyrrhiza glabra L. & $\begin{array}{l}+ \text { (as Glycyrrhiza } \\
\text { liquiritia) }\end{array}$ & - & - & - & - & $+^{*}$ \\
\hline Guaiacum officinale L. & $\begin{array}{l}+ \text { (as Lignum } \\
\text { guaiacum) }\end{array}$ & - & - & - & - & $+^{*}$ \\
\hline $\begin{array}{l}\text { Guaiacum sanctum L. or } G \text {. } \\
\text { officinale L. }\end{array}$ & $\begin{array}{l}+ \text { (as Lignum } \\
\text { guaiacum) }\end{array}$ & - & - & - & - & - \\
\hline Hedysarum spp. & - & - & - & - & - & - \\
\hline Helleborus niger L. & + & - & + & - & - & $+^{*}$ \\
\hline Indigofera spp. & - & - & - & - & - & + \\
\hline Inula helenium L. & + (as Elenium) & - & + & - & + & $+^{*}$ \\
\hline Juniperus spp. & $\begin{array}{l}+ \text { (as Juniperus, as } \\
\text { Sabina) }\end{array}$ & + & + (as I. communis) & + & $\begin{array}{l}+ \text { (as J. communis } \\
\text { L.) }\end{array}$ & $\begin{array}{l}+(\text { many } \\
\text { species*) }\end{array}$ \\
\hline Laurus nobilis L. & + (as Laurus) & $\begin{array}{l}+ \text { (as L. Alexandrina } \\
\text { Matthioli) }\end{array}$ & - & + & - & $+^{*}$ \\
\hline Lavandula spp. & + & - & - & + & - & $+^{*}$ \\
\hline Linum usitatissimum L. & + (as Linum) & - & + & + & + & $+^{*}$ \\
\hline Matricaria spp. & + (as Camomilla) & - & $\begin{array}{l}+ \text { (as } M . \\
\text { chamomilla, M. } \\
\text { parthenium) }\end{array}$ & + & $\begin{array}{l}+ \text { (as M. } \\
\text { chamomilla L.) }\end{array}$ & $\begin{array}{l}+(\text { as } M . \\
\text { chamomilla* }, M . \\
\text { discoidea*) }\end{array}$ \\
\hline Melissa officinalis L. & + (as Melissa) & - & $\begin{array}{l}+ \text { (as } M . \\
\text { calamintha) }\end{array}$ & + & + & $+^{*}$ \\
\hline $\begin{array}{l}\text { Mentha aquatica L. var. } \\
\text { crispa (L.) Benth. }\end{array}$ & $\begin{array}{l}+ \text { (as Mentha } \\
\text { aquatica) }\end{array}$ & - & - & + & + (as Mentha spp.) & + \\
\hline Myristica fragrans Houtt. & - & - & - & - & - & - \\
\hline $\begin{array}{l}\text { Myroxylon balsamum (L.) } \\
\text { Harms }\end{array}$ & - & - & - & - & - & $+^{*}$ \\
\hline Nasturtium officinale R.Br. & $\begin{array}{l}+ \text { (as Nasturcium } \\
\text { aquaticum) }\end{array}$ & - & - & + & + & $+^{*}$ \\
\hline Olea europaea L. & + (as Olea domestica) & - & - & + & - & - \\
\hline Ononis spinosa L. & + (as Ononis) & - & + (as 0. aruensis) & - & + & $+^{*}$ \\
\hline Origanum majorana L. & + (as Maiorana) & - & - & - & - & $t^{*}$ \\
\hline $\begin{array}{l}\text { Persicaria bistorta }(\mathrm{L} .) \\
\text { Samp. = Polygonum } \\
\text { bistorta L. }\end{array}$ & + (as Bistorta) & - & + & - & + & - \\
\hline Petasites sp. & $\begin{array}{l}+ \text { (as Petasites falso } \\
\text { dieta) }\end{array}$ & + & $\begin{array}{l}+ \text { (as Tussilago } \\
\text { petasites) }\end{array}$ & - & - & $\begin{array}{l}+(\text { many } \\
\left.\text { species }{ }^{*}\right)\end{array}$ \\
\hline $\begin{array}{l}\text { Petroselinum crispum (Mill.) } \\
\text { Fuss. }\end{array}$ & $\begin{array}{l}+ \text { (as Pertoselinum } \\
\text { vulgare) }\end{array}$ & - & - & - & - & $+\left(\right.$ as $P$. sativum $\left.{ }^{*}\right)$ \\
\hline $\begin{array}{l}\text { Peucedanum ostruthium } \\
\text { (L.) W.D.J. Koch = } \\
\text { Imperatoria ostruthium L. }\end{array}$ & - & - & + & - & - & + \\
\hline Pimpinella anisum $\mathrm{L}$. & + (as Anisum) & $\begin{array}{l}+ \text { (as P. major L. } \\
\text { Huds, P. minorcrispa) }\end{array}$ & - & + & + & $+^{*}$ \\
\hline Piper longum L. & - & - & - & - & - & - \\
\hline $\begin{array}{l}\text { Potentilla erecta (L.) } \\
\text { Räusch. }\end{array}$ & + (as Tormentilla) & - & $\begin{array}{l}+ \text { (as Tormentilla } \\
\text { erecta) }\end{array}$ & - & - & $\begin{array}{l}+(\text { as } P . \\
\text { tormentilla*) }\end{array}$ \\
\hline Pterocarpus santalinus L. fil. & - & - & - & + & - & - \\
\hline
\end{tabular}


Table 1 Medicinal plants listed in Krummhübel herbalist recipes (seventeenth to nineteenth centuries) and their occurrences in manuscripts and regional surveys, including Matthioli [11], Schwenckfeld [3], Mattuschka [12], Kneipp [13], Fischer [14] and Madaus [15] (Continued)

\begin{tabular}{|c|c|c|c|c|c|c|}
\hline $\begin{array}{l}\text { Krummhübel herbalists, } \\
\text { seventeenth to nineteenth } \\
\text { centuries }\end{array}$ & Matthioli (1563) [11] & $\begin{array}{l}\text { Schwenckfeld (1607) } \\
\text { [3] }\end{array}$ & $\begin{array}{l}\text { Mattuschka (1779) } \\
{[12]^{\mathrm{a}}}\end{array}$ & $\begin{array}{l}\text { Kneipp (1892) } \\
{[13]}\end{array}$ & $\begin{array}{l}\text { Fischer (1930's) } \\
{[14]^{\mathrm{b}}}\end{array}$ & $\begin{array}{l}\text { Madaus (1938) } \\
{[15]}\end{array}$ \\
\hline Pulicaria vulgaris Gaertn. & - & - & - & - & + & - \\
\hline Pyrus sp. & + & - & - & - & $\begin{array}{l}+ \text { (as P. communis } \\
\text { L.) }\end{array}$ & $+($ as P. malus*) \\
\hline Rheum rhabarbarum L. & + & - & - & - & - & - \\
\hline Rosa spp. & + & $\begin{array}{l}+ \text { (as } R . \text { alpina, } R \\
\text { rubra) }\end{array}$ & $\begin{array}{l}+(\text { as } R . \text { canina, } R \\
\text { alba) }\end{array}$ & + & + & $\begin{array}{l}+(\text { many } \\
\text { species*) }\end{array}$ \\
\hline Rosmarinus officinalis $\mathrm{L}$. & $\begin{array}{l}+ \text { (as Rosmarinus } \\
\text { coronaria) }\end{array}$ & + (as $R$. sylvaticus) & - & + & + & $+^{*}$ \\
\hline Sassafras spp. & - & - & - & - & - & $+^{*}$ \\
\hline Scabiosa spp. & + (as Scabiosa minor) & - & $\begin{array}{l}+ \text { (as Scabiosa } \\
\text { succisa and S. } \\
\text { aruensis) }\end{array}$ & - & $\begin{array}{l}+ \text { (as Succisa } \\
\text { pratensis Moench = } \\
\text { Scabiosa succisa L.) }\end{array}$ & $\begin{array}{l}+(\text { different } \\
\text { species*) }\end{array}$ \\
\hline Senna spp. & + (as Sena) & - & - & - & - & $+^{*}$ \\
\hline $\begin{array}{l}\text { Silene baccifera }(\mathrm{L} \text {.) Roth }= \\
\text { Cucubalus baccifer } \mathrm{L} \text {. }\end{array}$ & - & - & - & - & - & - \\
\hline $\begin{array}{l}\text { Stachys officinalis (L.) Trevis } \\
=\text { Betonica officinalis } \mathrm{L} \text {. }\end{array}$ & + (as Betonica) & - & + & - & + & + \\
\hline Styrax spp. & + & - & - & - & - & - \\
\hline $\begin{array}{l}\text { Syzygium aromaticum (L.) } \\
\text { Merr. \& L.M.Perry }\end{array}$ & - & - & - & - & - & - \\
\hline Vaccinium vitis-idaea $\mathrm{L}$. & - & - & + & + & + (as V. myrtillus L.) & $+^{*}$ \\
\hline Veronica spp. & $\begin{array}{l}+ \text { (as Veronica mas, V. } \\
\text { foemina) }\end{array}$ & + & $\begin{array}{l}+ \text { (as } V \text {. officinalis, } \\
V . \text { beccabunga) }\end{array}$ & + & + & $\begin{array}{l}+(\text { many } \\
\text { species*) }\end{array}$ \\
\hline Viola spp. & + (as Viola purpurea) & - & + (as V. odorata) & + & + & $\begin{array}{l}+(\text { many } \\
\text { species*) }\end{array}$ \\
\hline Zingiber officinale Roscoe & + (as Zinziber) & - & - & - & + & $+^{*}$ \\
\hline$\Sigma=72$ & $\Sigma=48$ & $\Sigma=11$ & $\Sigma=25$ & $\Sigma=24$ & $\Sigma=33$ & $\Sigma=55$ \\
\hline
\end{tabular}

*Denotes to Madaus [15], asterisk shows the description of use or recipe; no asterisk-plant was only listed

${ }^{a}$ The register of Mattuschka [12] includes only species listed by the author as having medicinal properties

${ }^{b}$ Based on Kujawska et al. [14]

the Russian Federation (not disaggregated by Russiain-Europe) and Poland) being the top 20 global importers by volume of pharmaceutical plants. The top six exporters of these plants in Europe include Germany, Poland, Spain, Bulgaria, Albania and France [71, 72]. A large part of modern drugs has its roots in ancient traditions. Until today, ancient scripts have exerted a strong influence on the use of herbal medicine, and the repeated empirical testing and scientific study of health care claims guide and shape the selection of efficacious treatments and evidence-based herbal medicine [73].

Medicinal plants used by herbalists from Krummhübel were remedies for multiple ailments. The taxa that achieved the highest use or were recognised as the most versatile remedies with multiple pharmacological indications were Aloë spp., Copaifera officinalis L., Guaiacum officinale L., Commiphora spp. and Crocus (probably) sativus L. Comparison of the uses of the plants considered with their contemporary use, described in publications involved with herbal medicine and pharmacognosy (e.g. [36, 74-77]), showed some novelties.

The most frequently mentioned properties of Aloë spp. are gastrointestinal activities, hepato-protective properties and beneficial effects against skin problems such as wounds, injuries and infective diseases in both the Islamic traditional medicine [78] and in modern medicine [36, 74, 76, 77]. According to Krummhübel herbalists, it has also antihelminthic properties and can be used as a remedy for the treatment of scurvy.

Copaiba (Copaifera sp.) has a wide range of ethnopharmacological indications, including the treatment of the following: cystitis, urinary incontinence, gonorrhoea and syphilis; respiratory ailments including bronchitis, strep throat, haemoptysis, pneumonia and sinusitis; infections in the skin and mucosa such as dermatitis, eczema, psoriasis and wounds; ulcers and lesions of the 


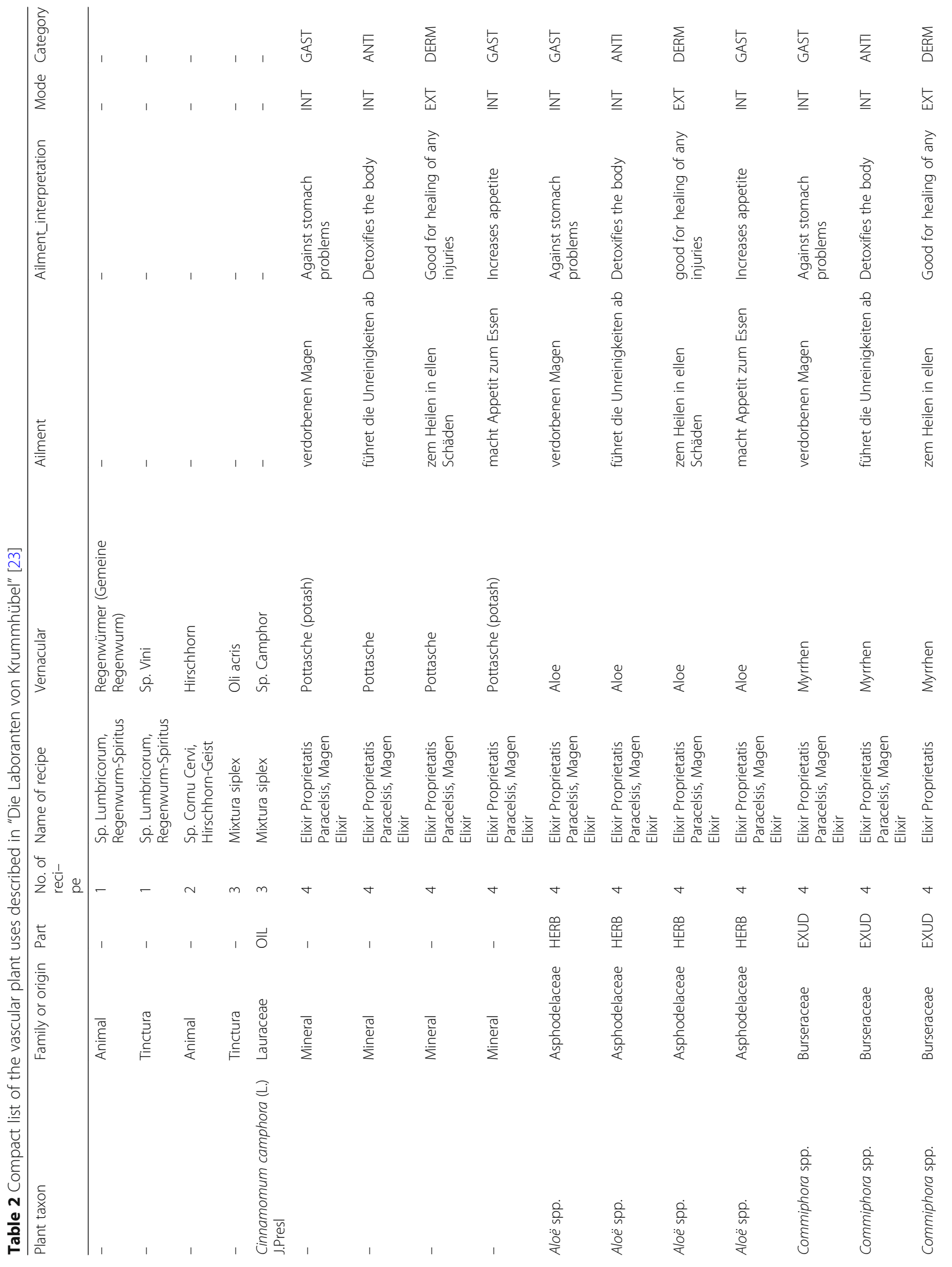




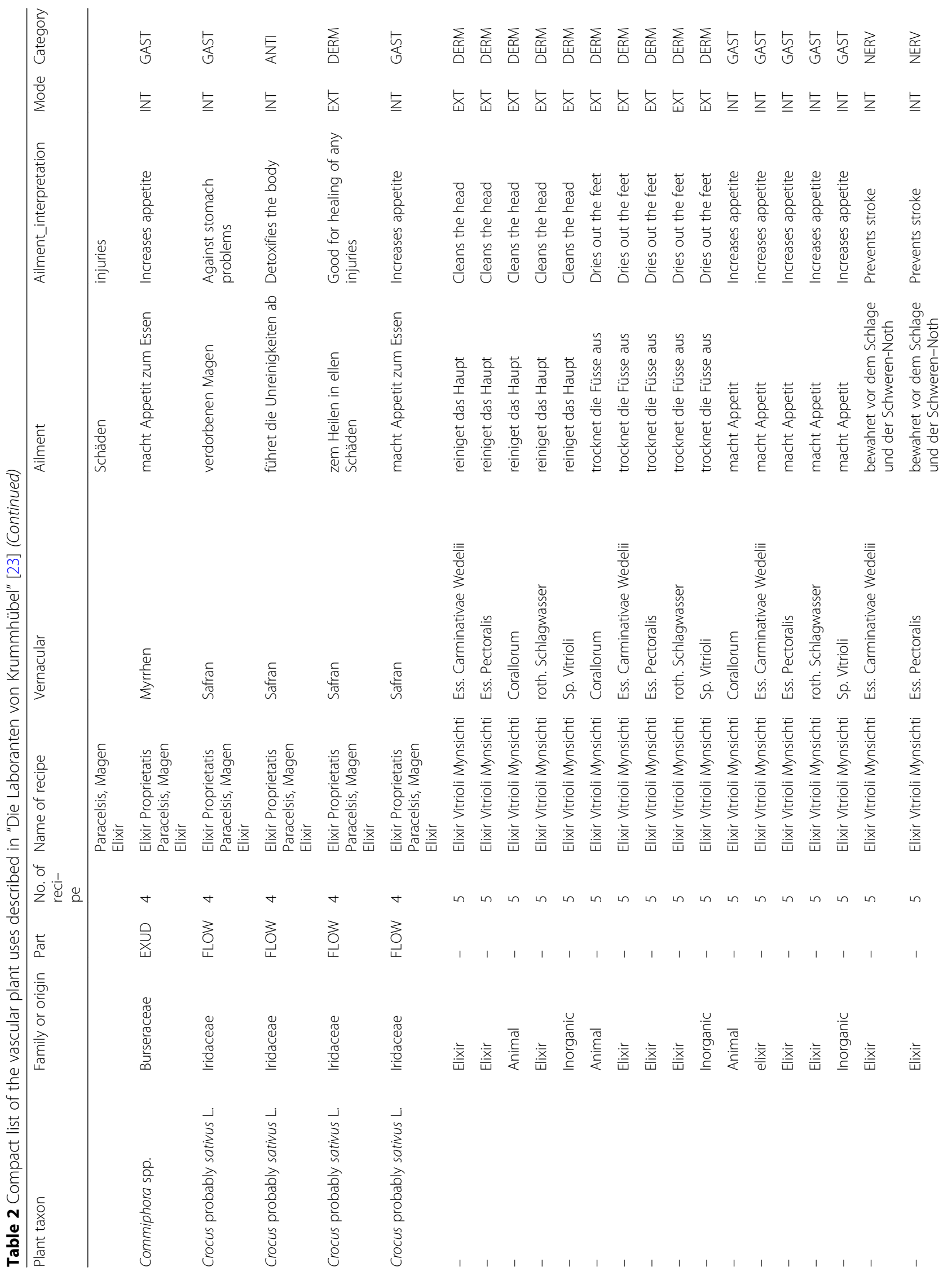




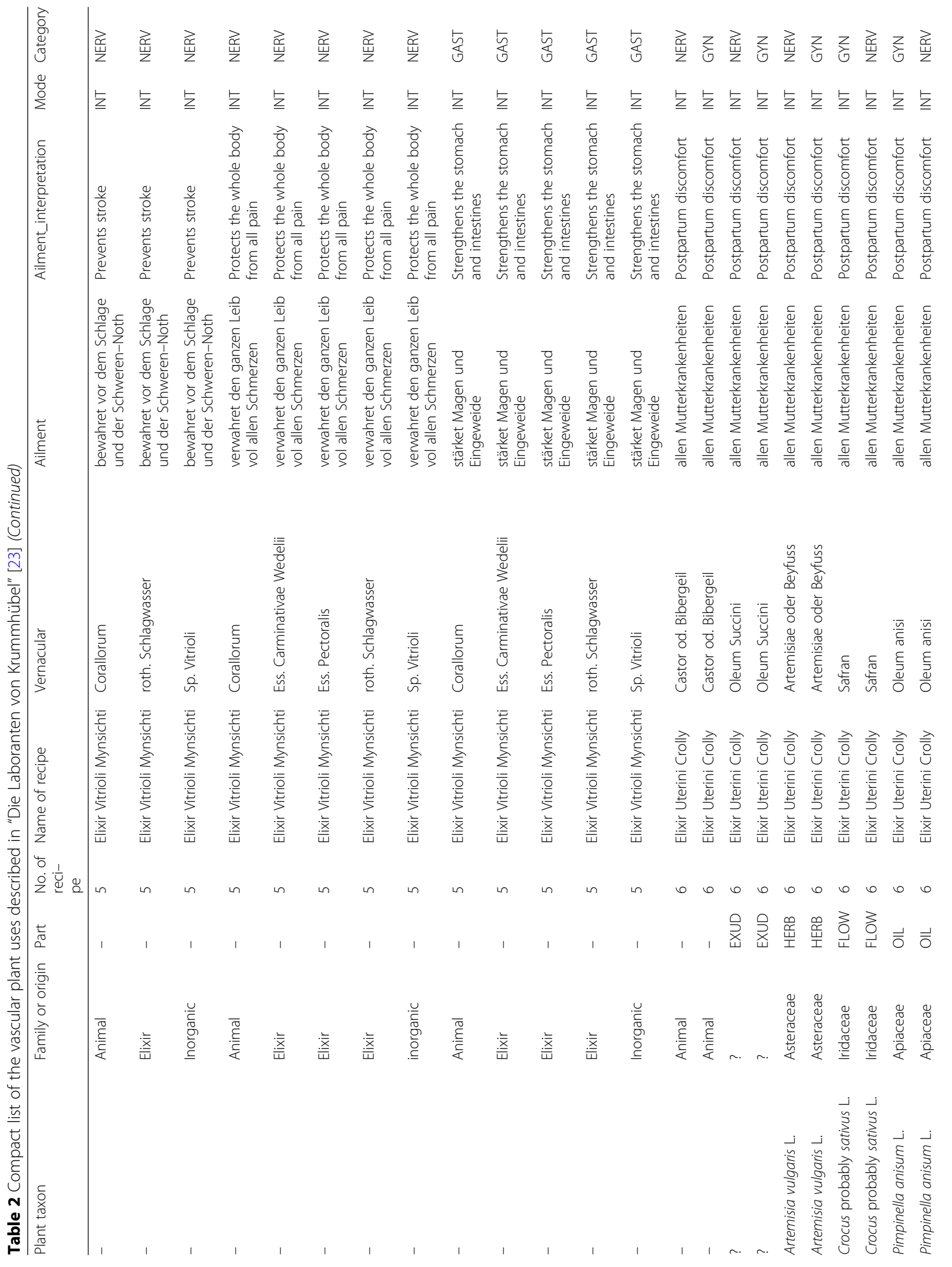




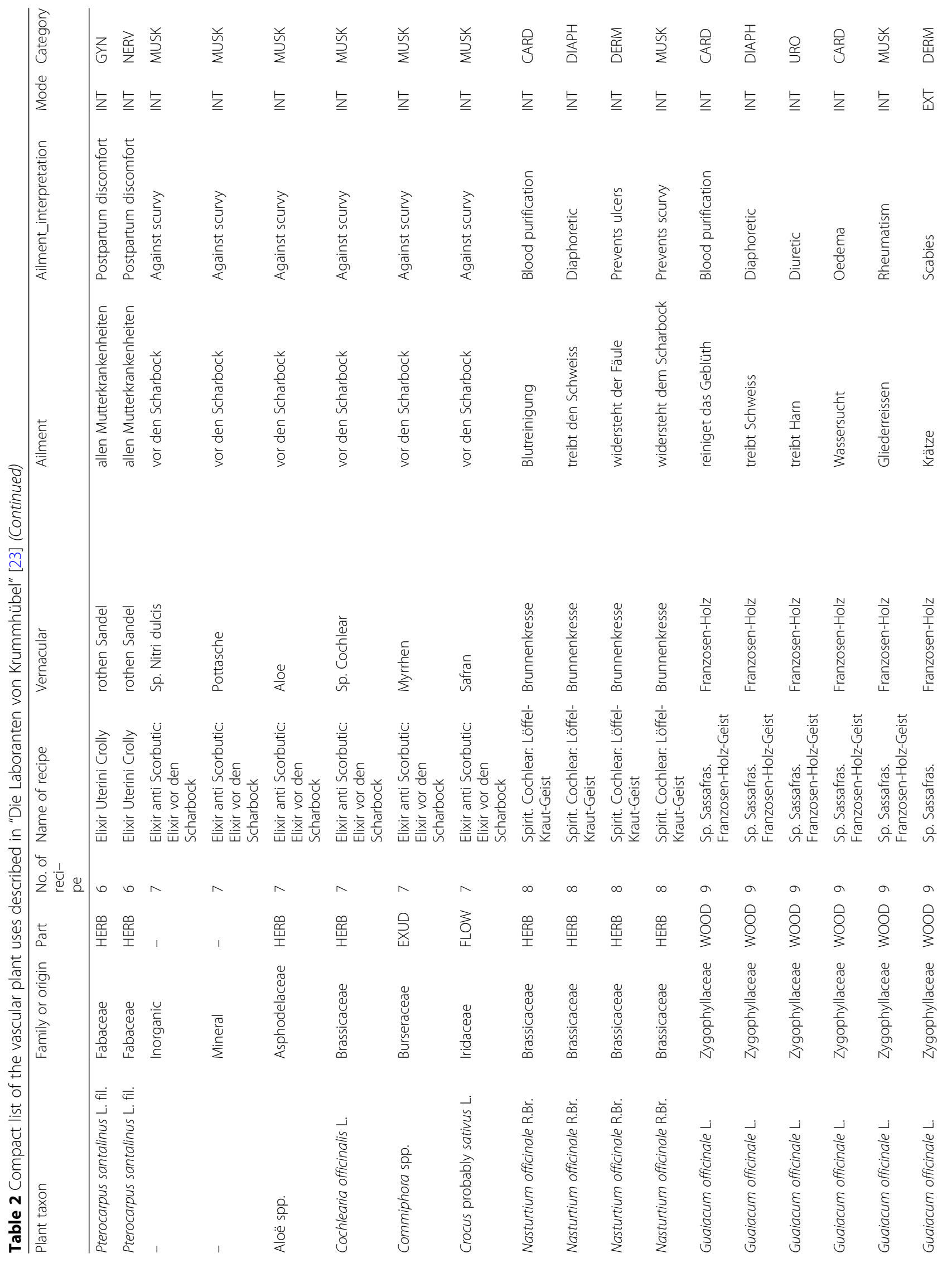




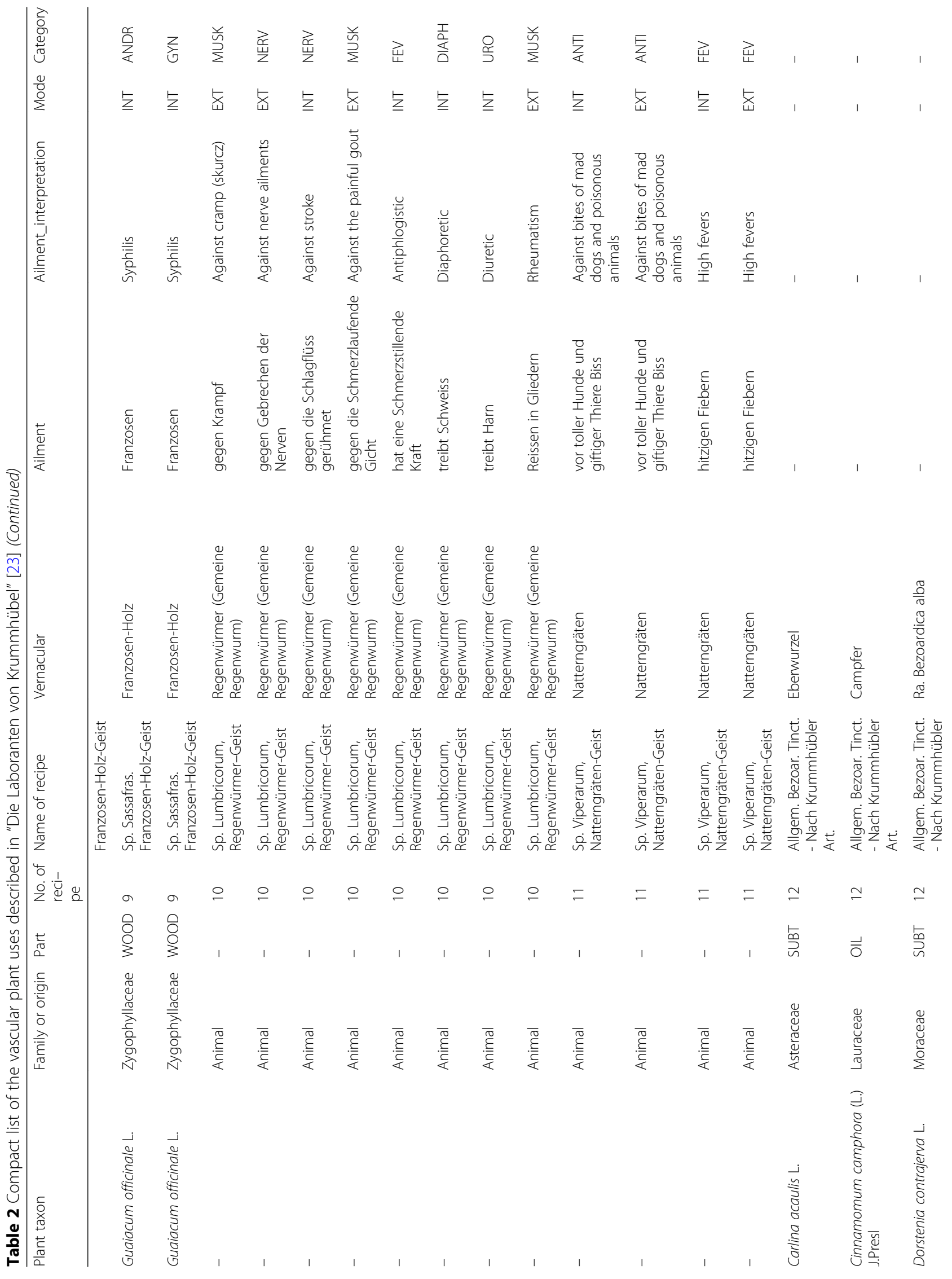




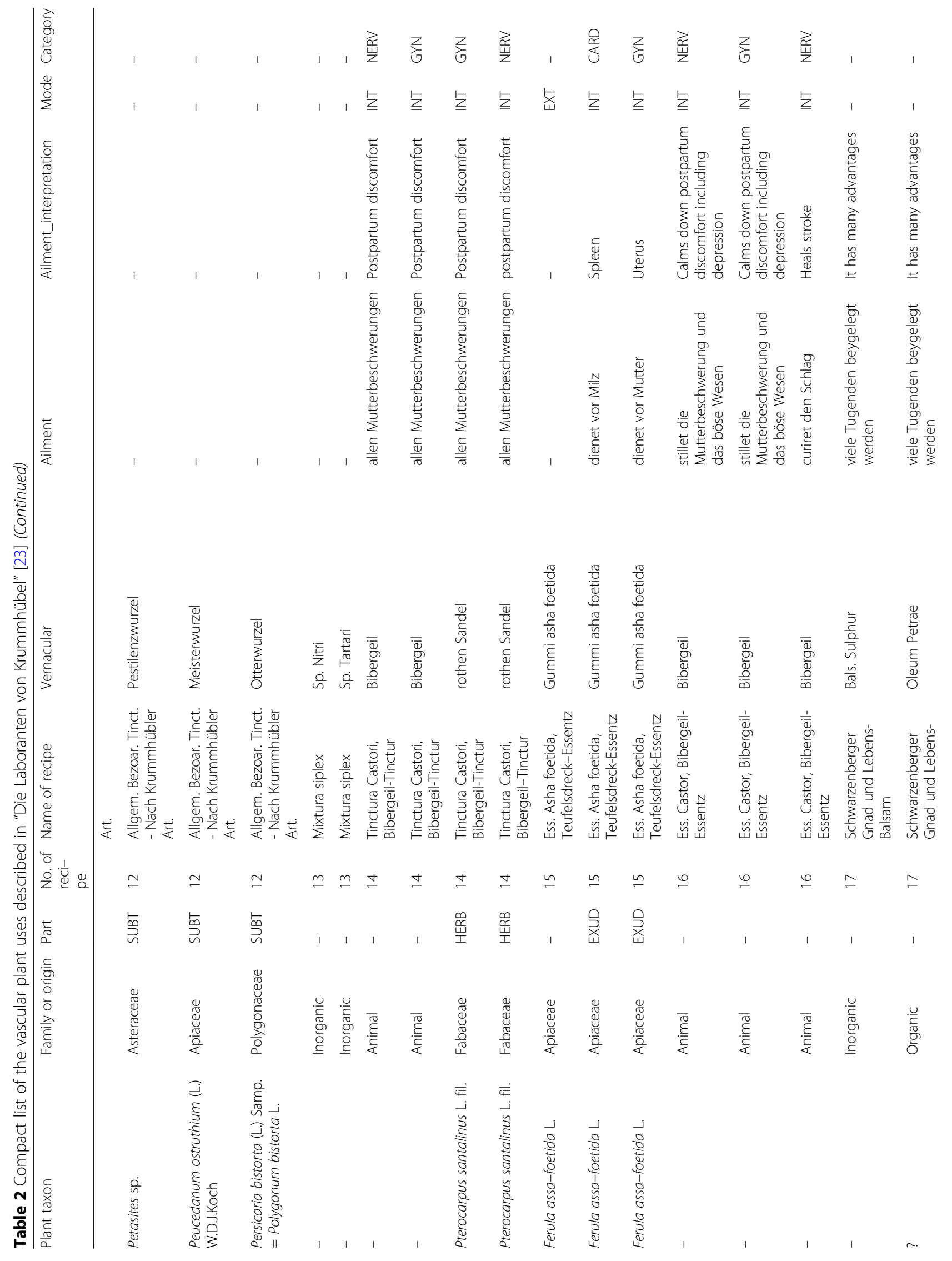




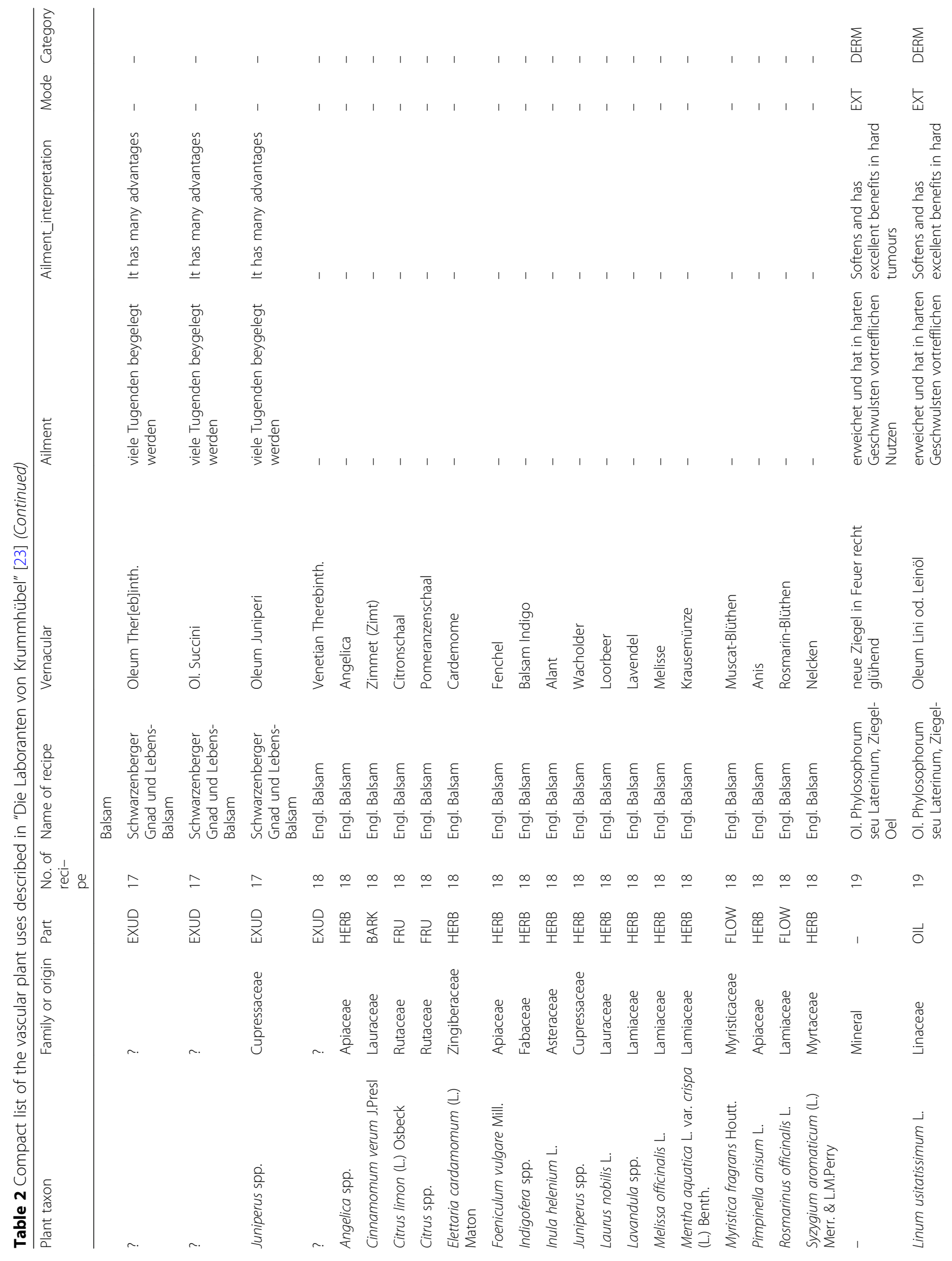




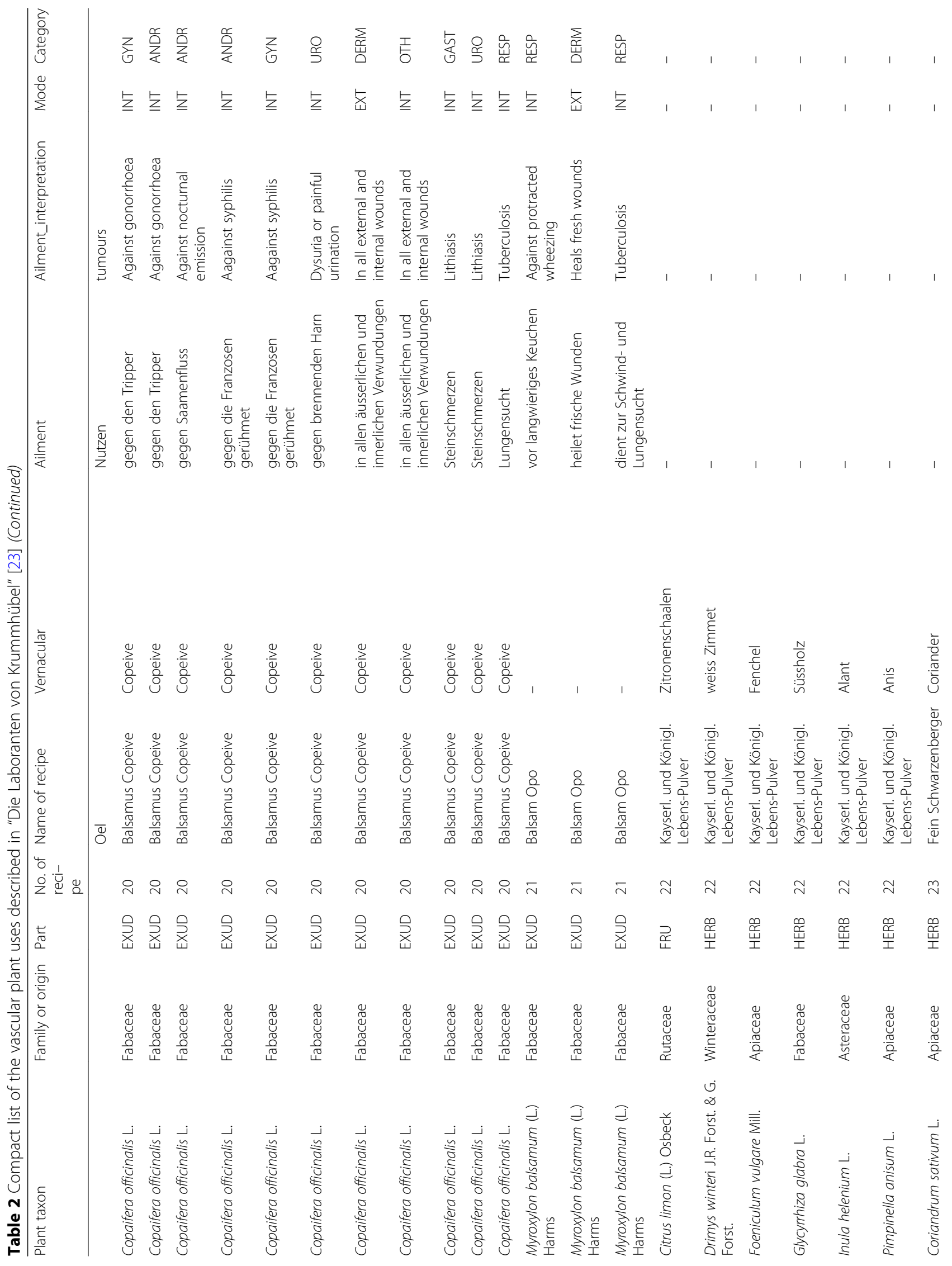




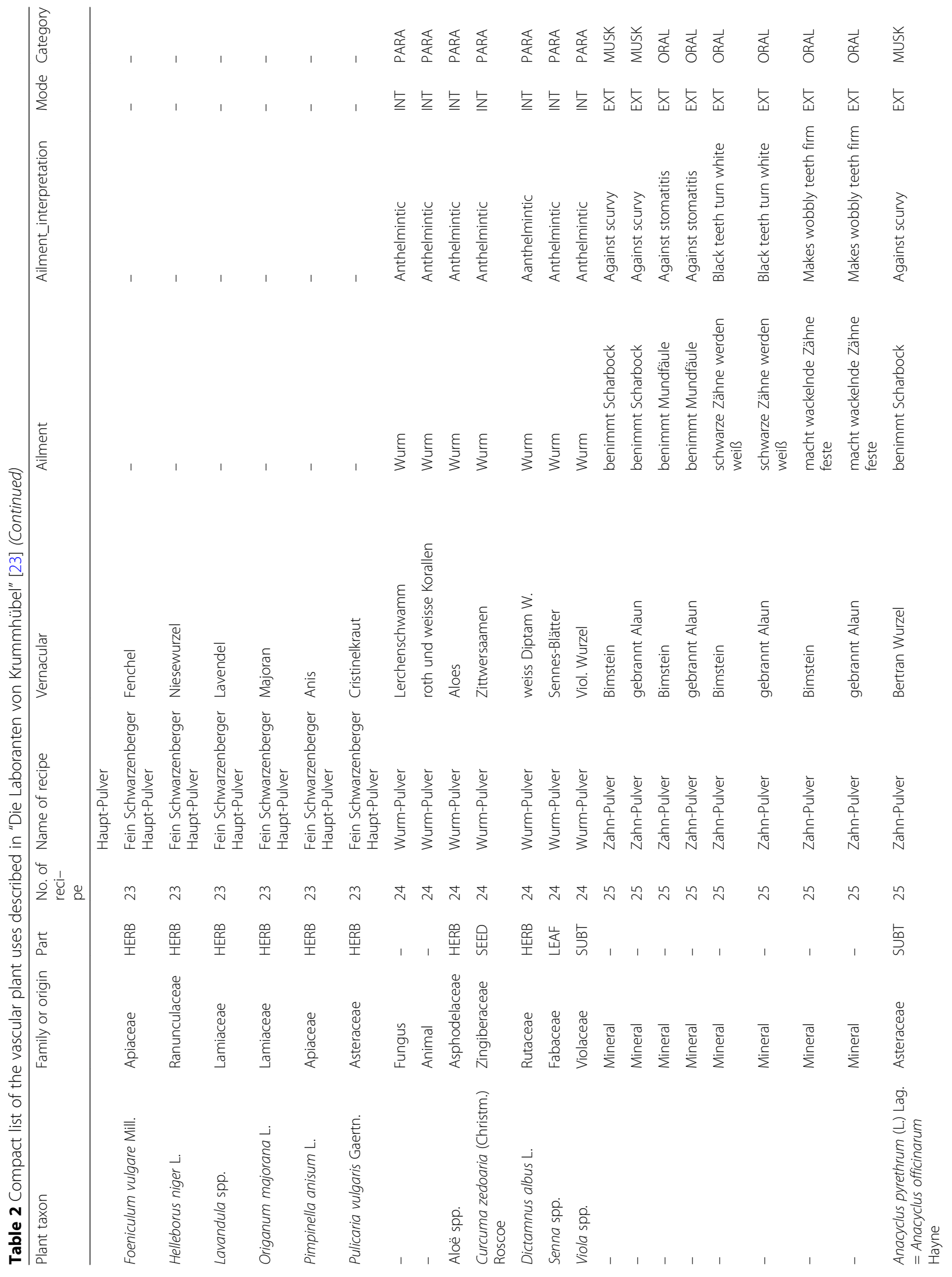




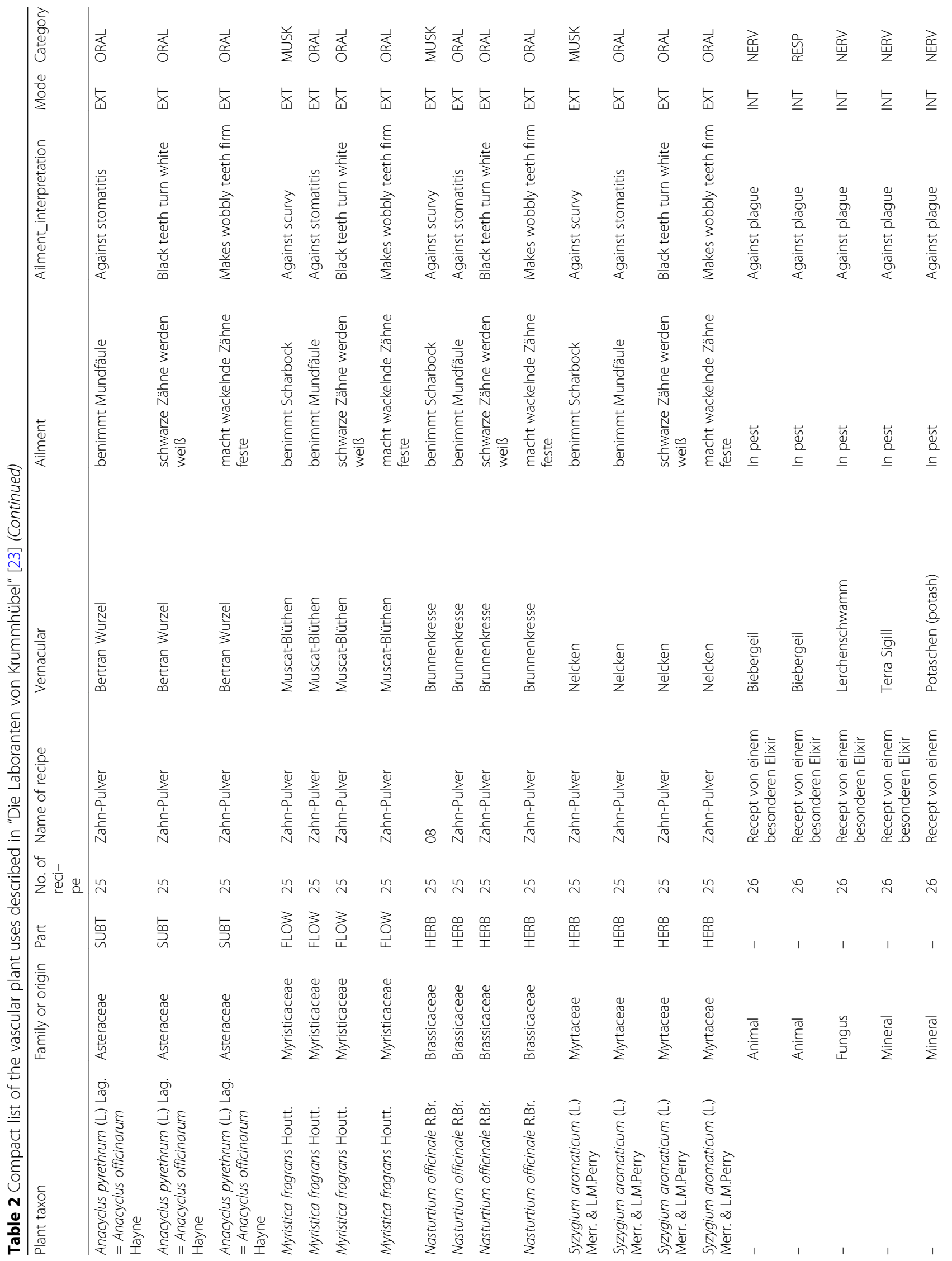




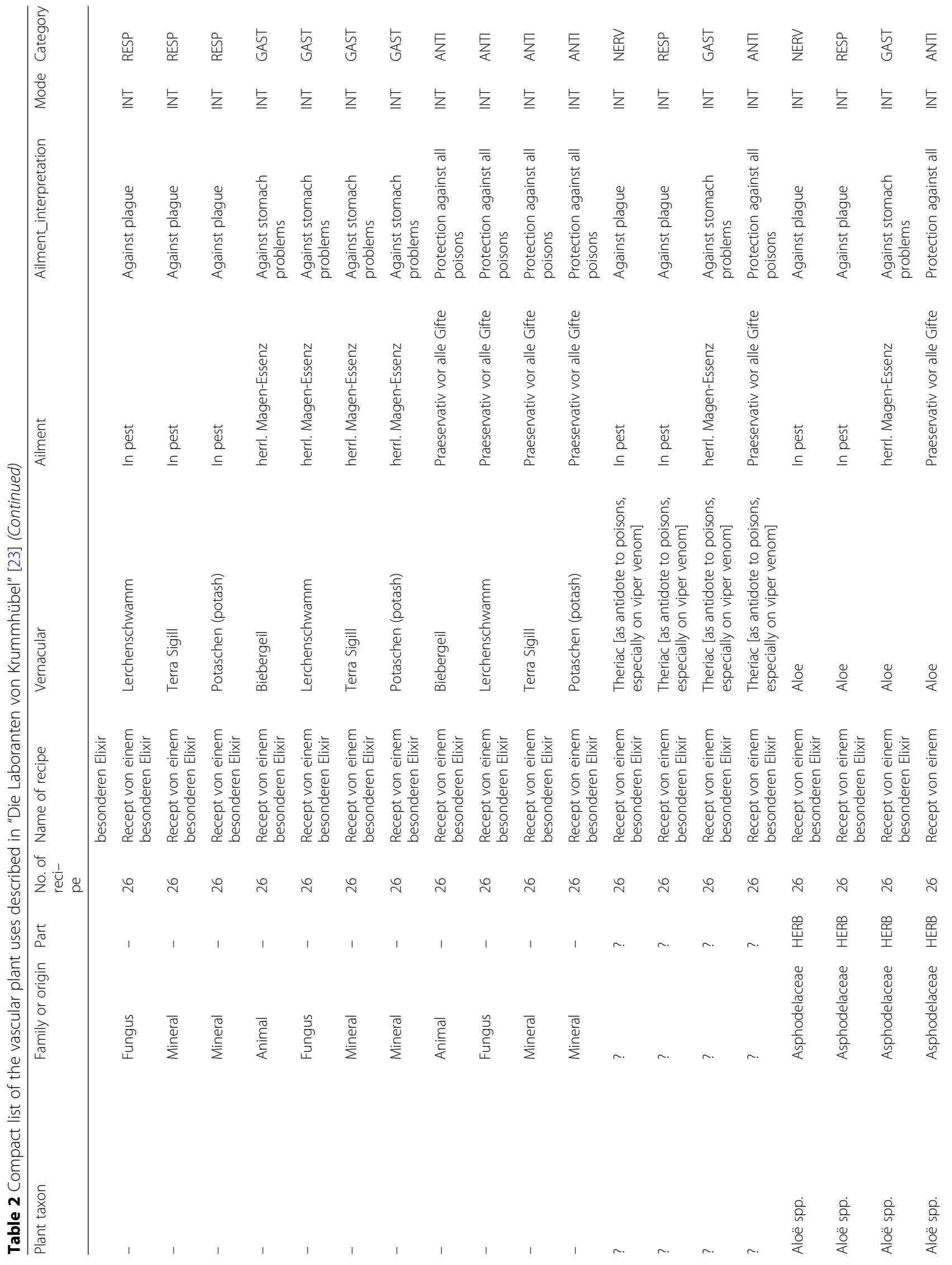




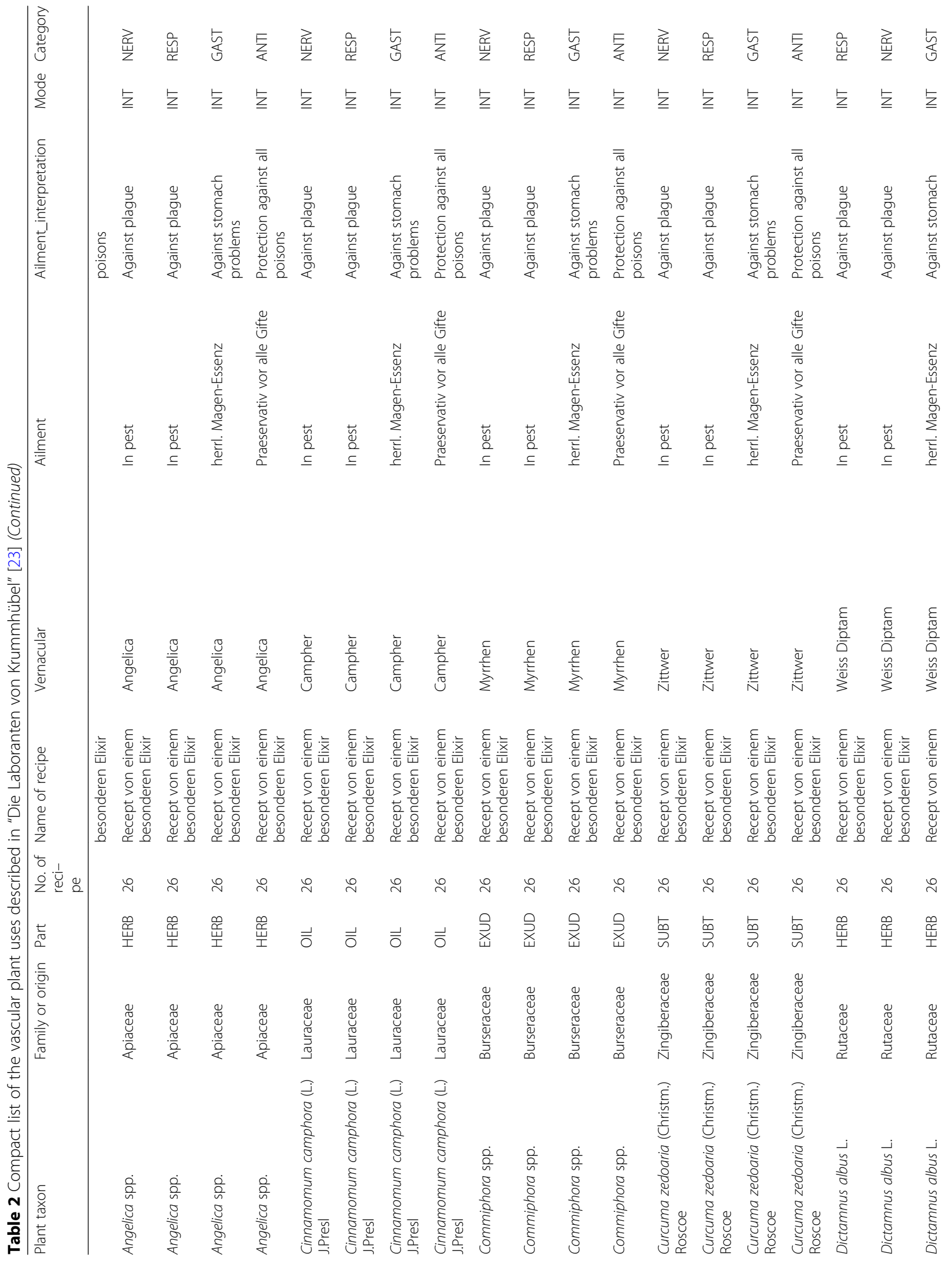




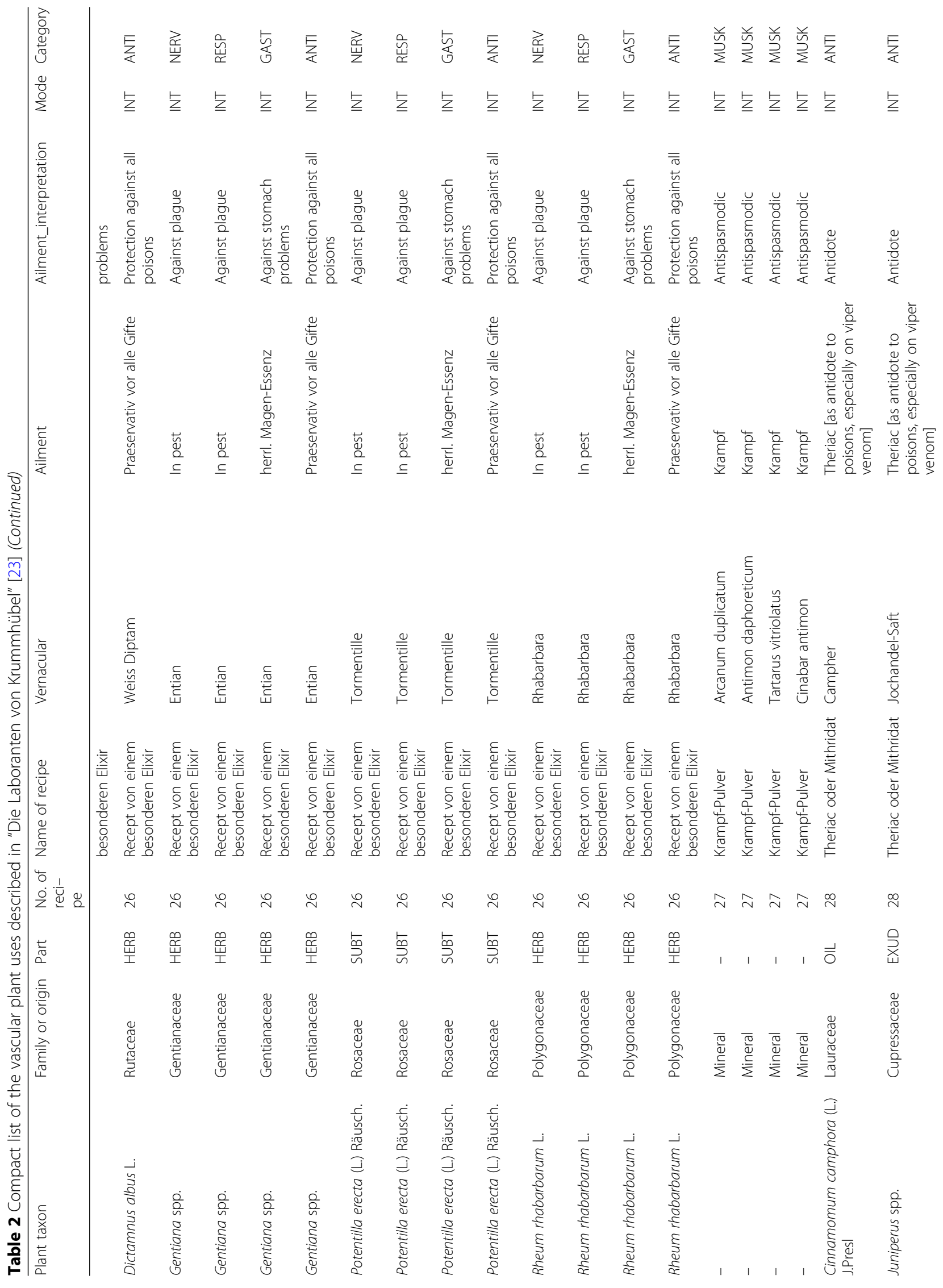




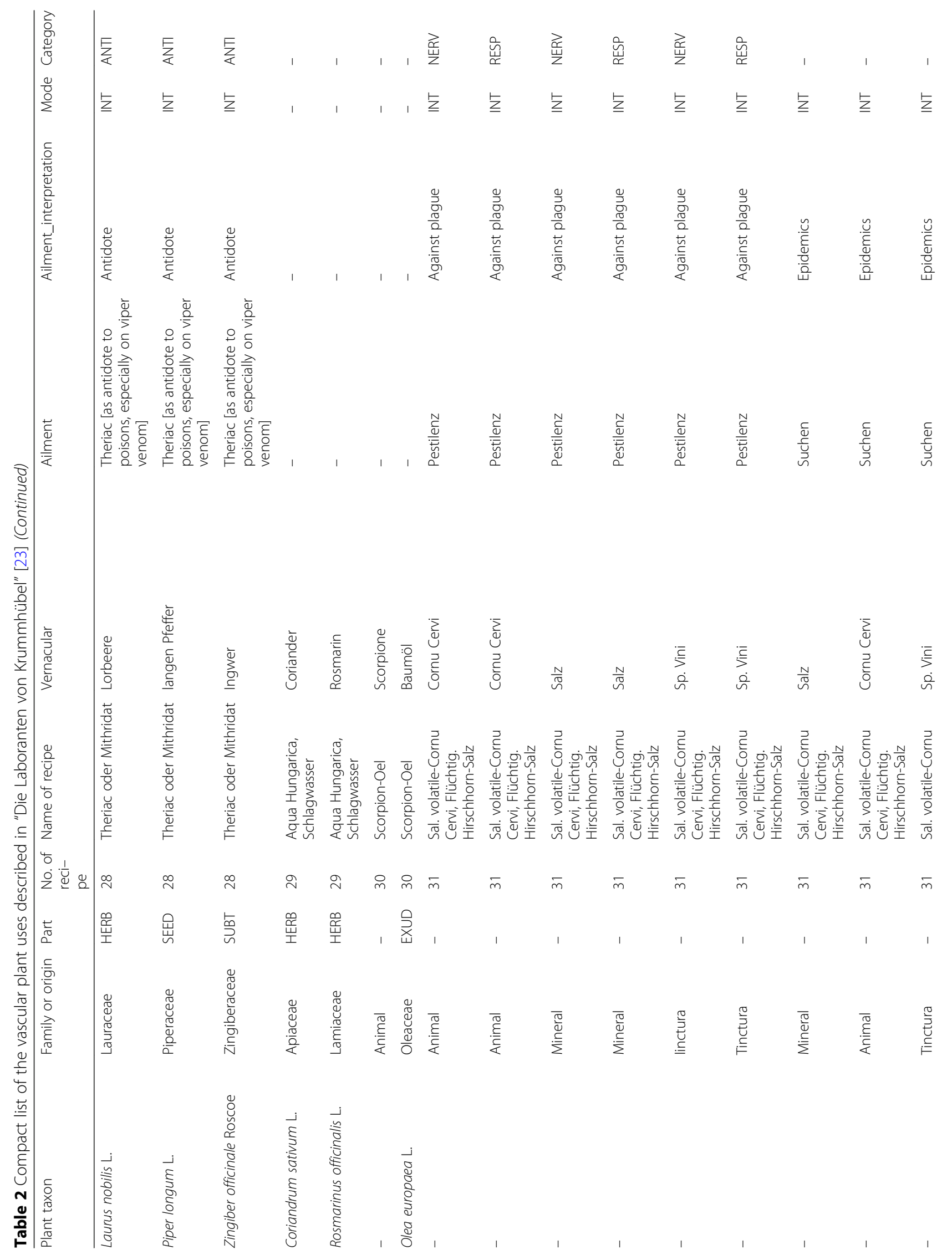




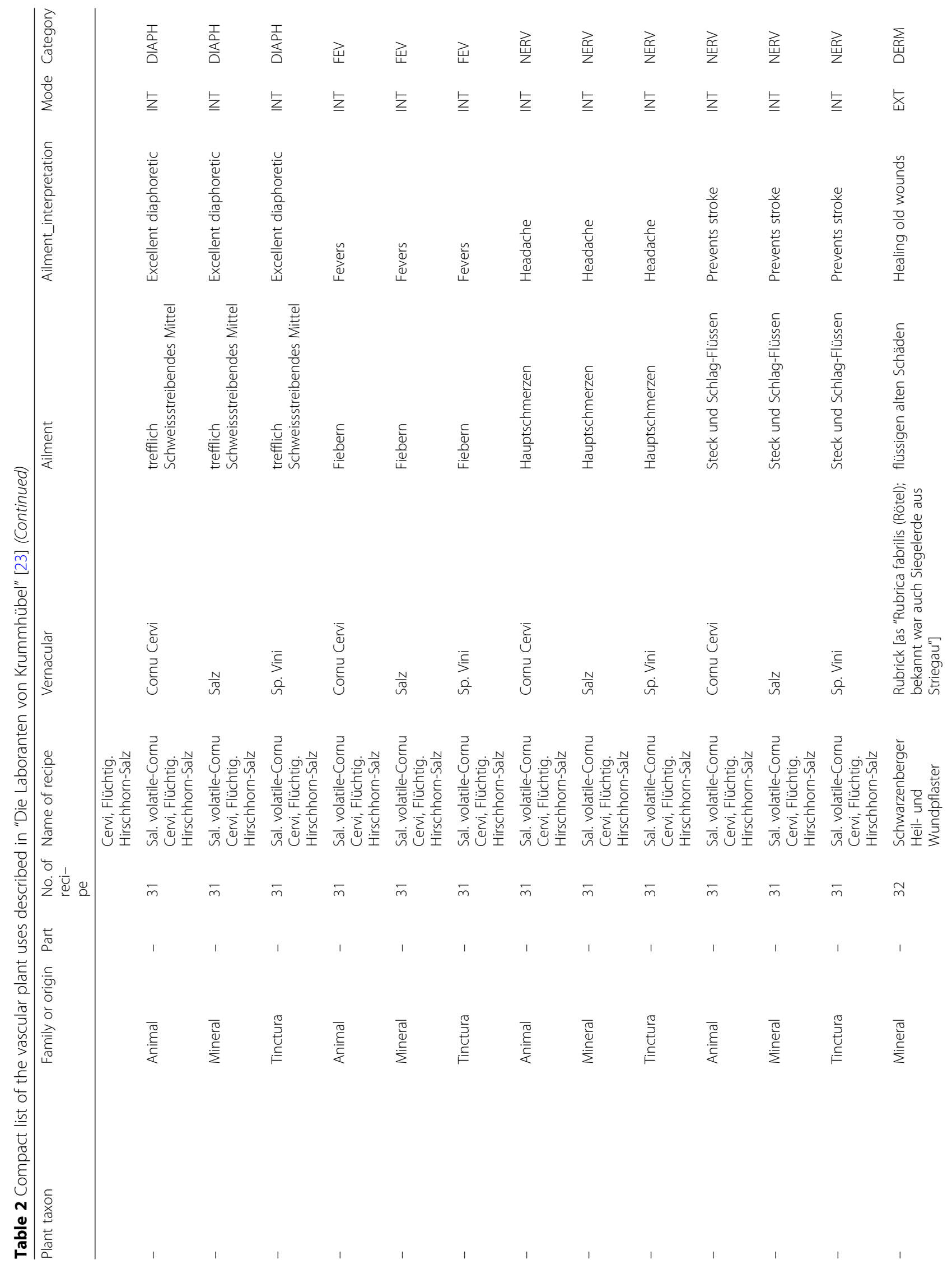




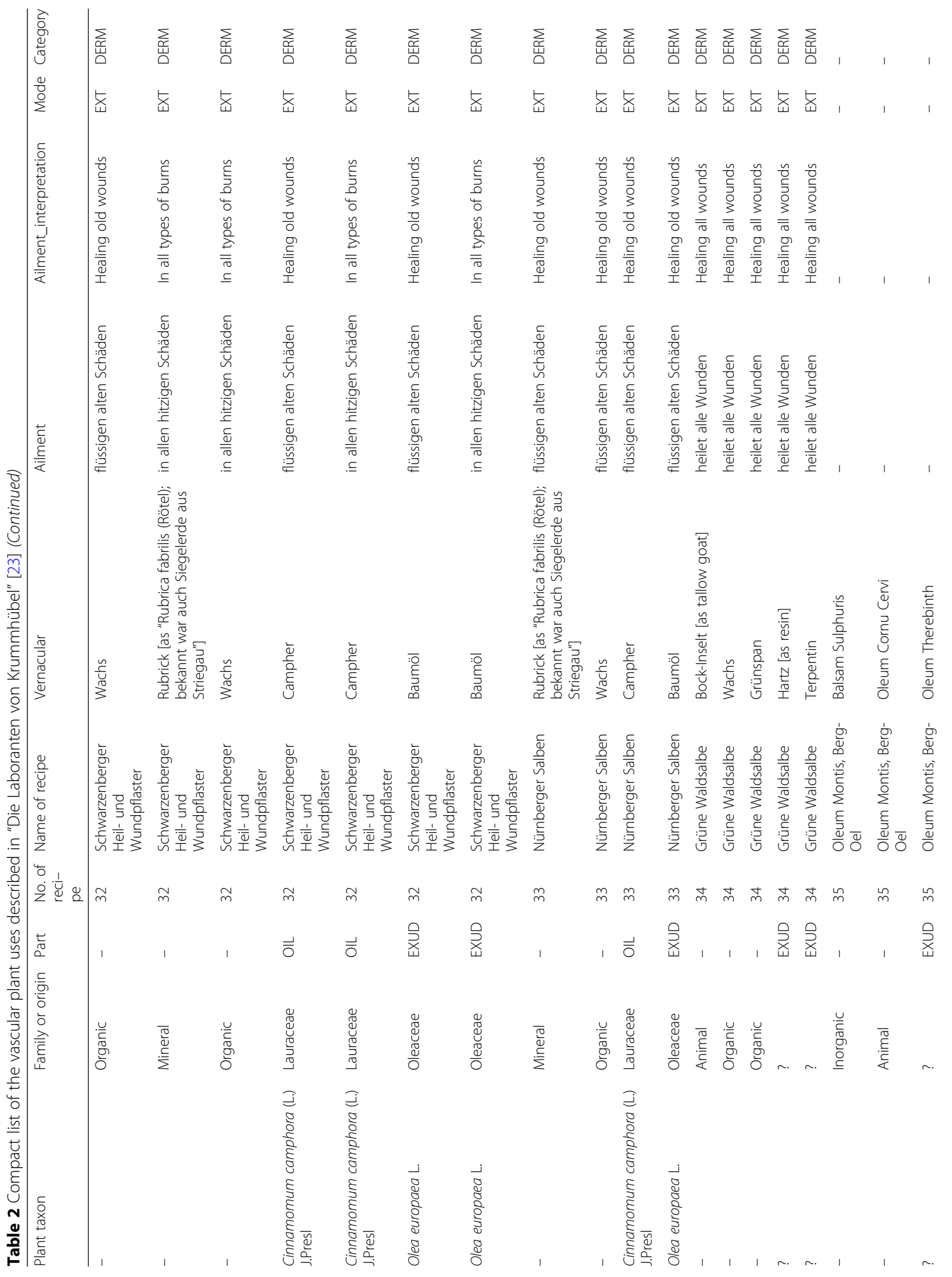




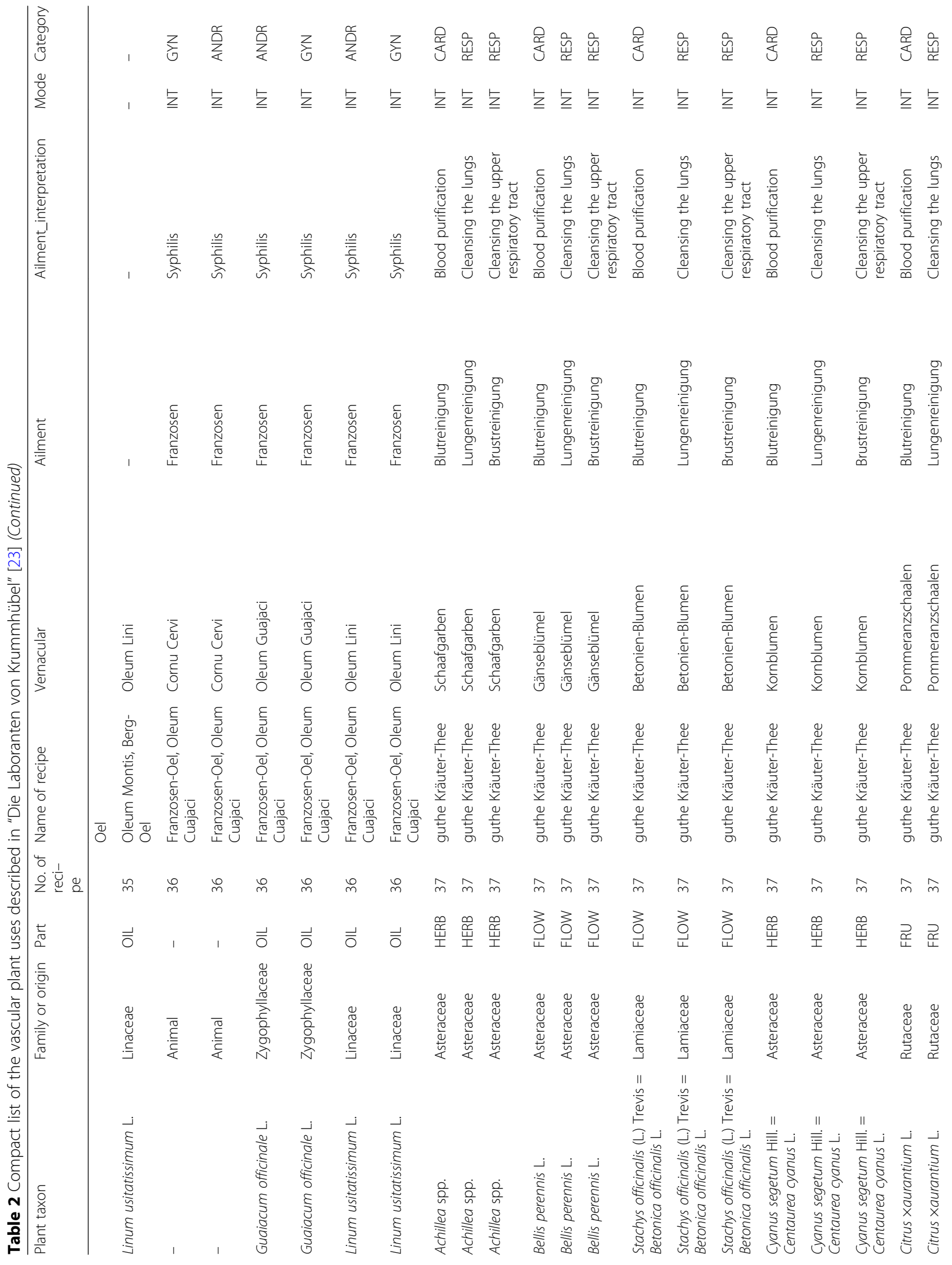




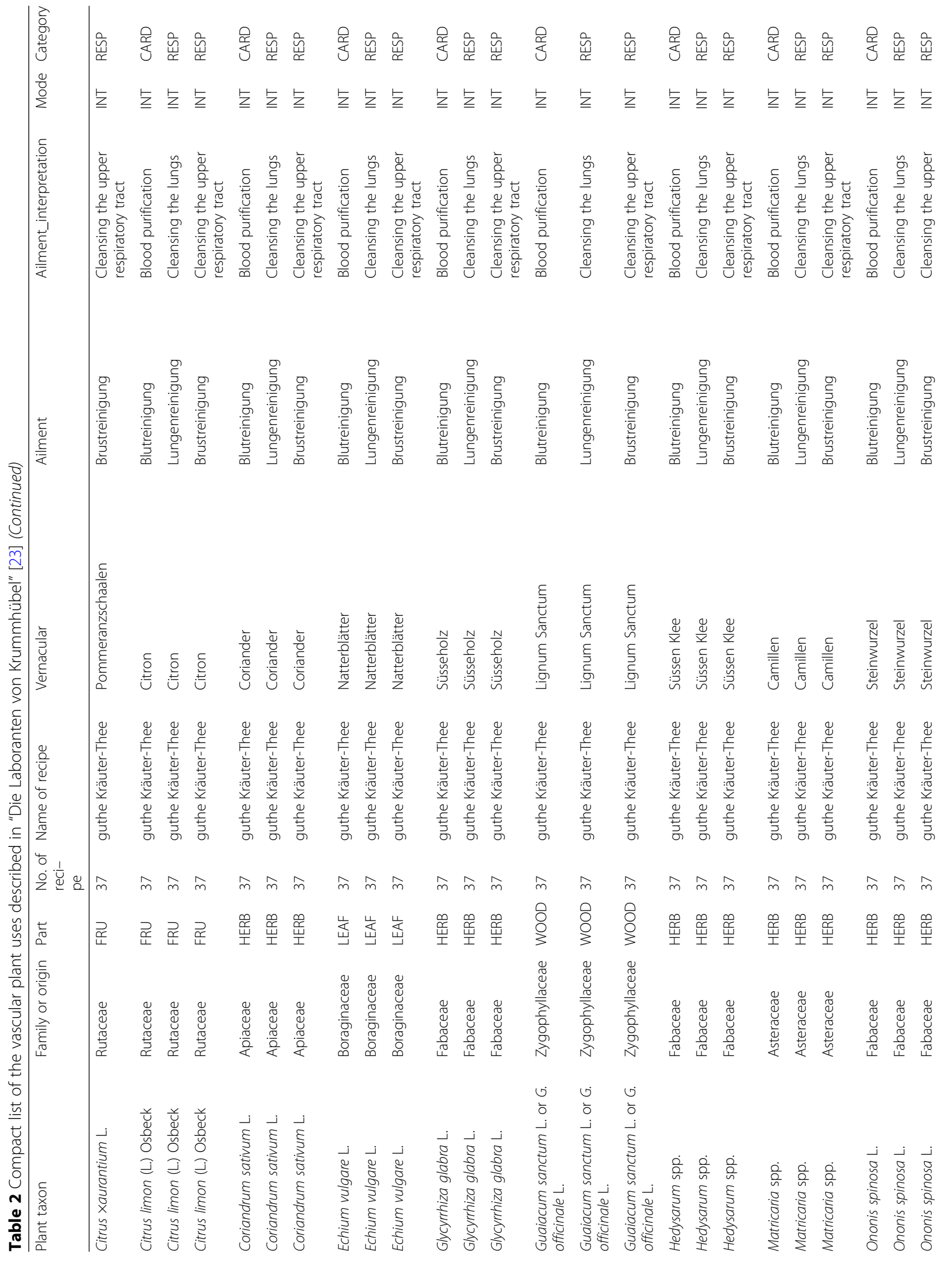




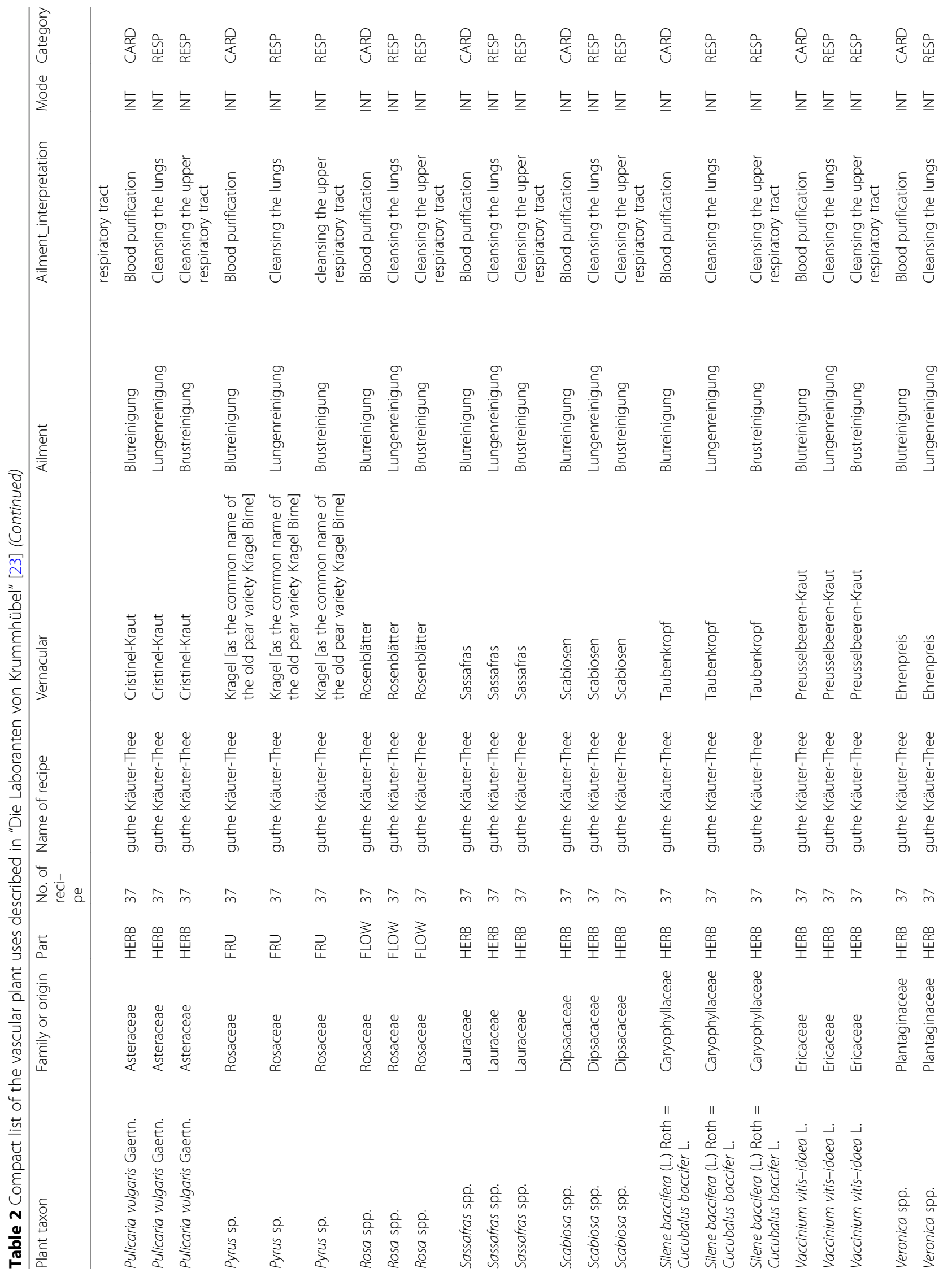


Spałek et al. Journal of Ethnobiology and Ethnomedicine $\quad$ (2019) 15:24

Page 34 of 39

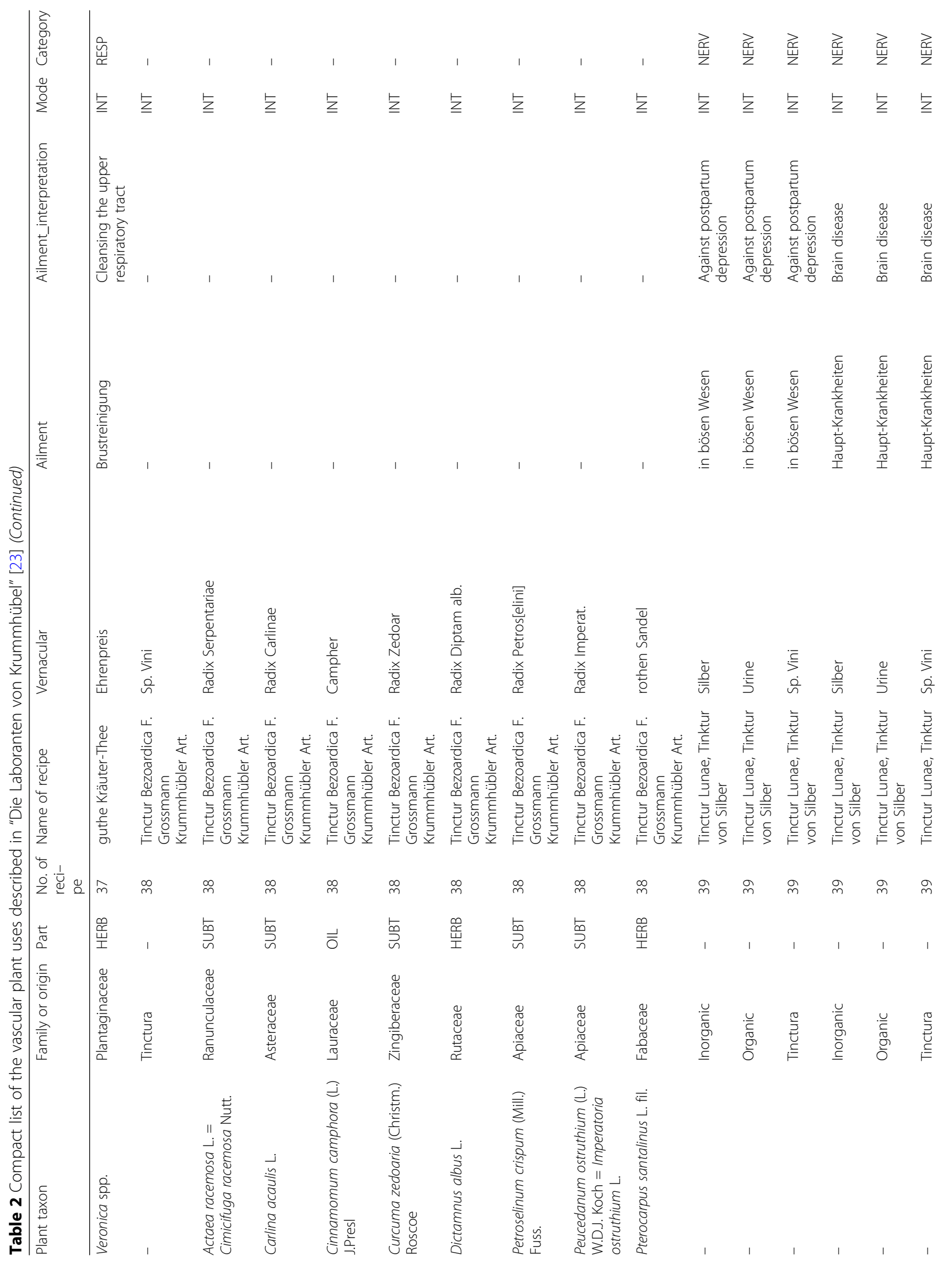




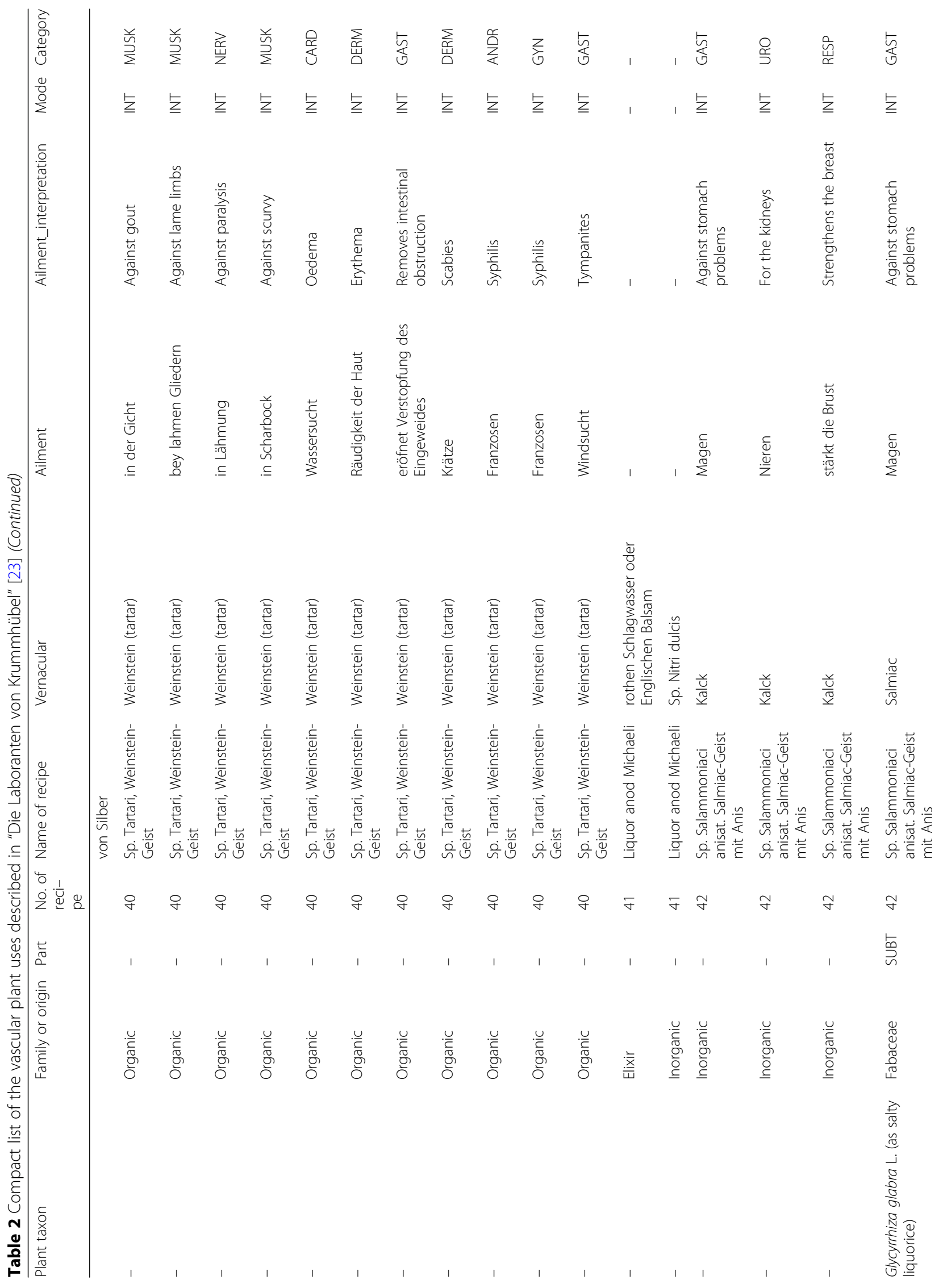




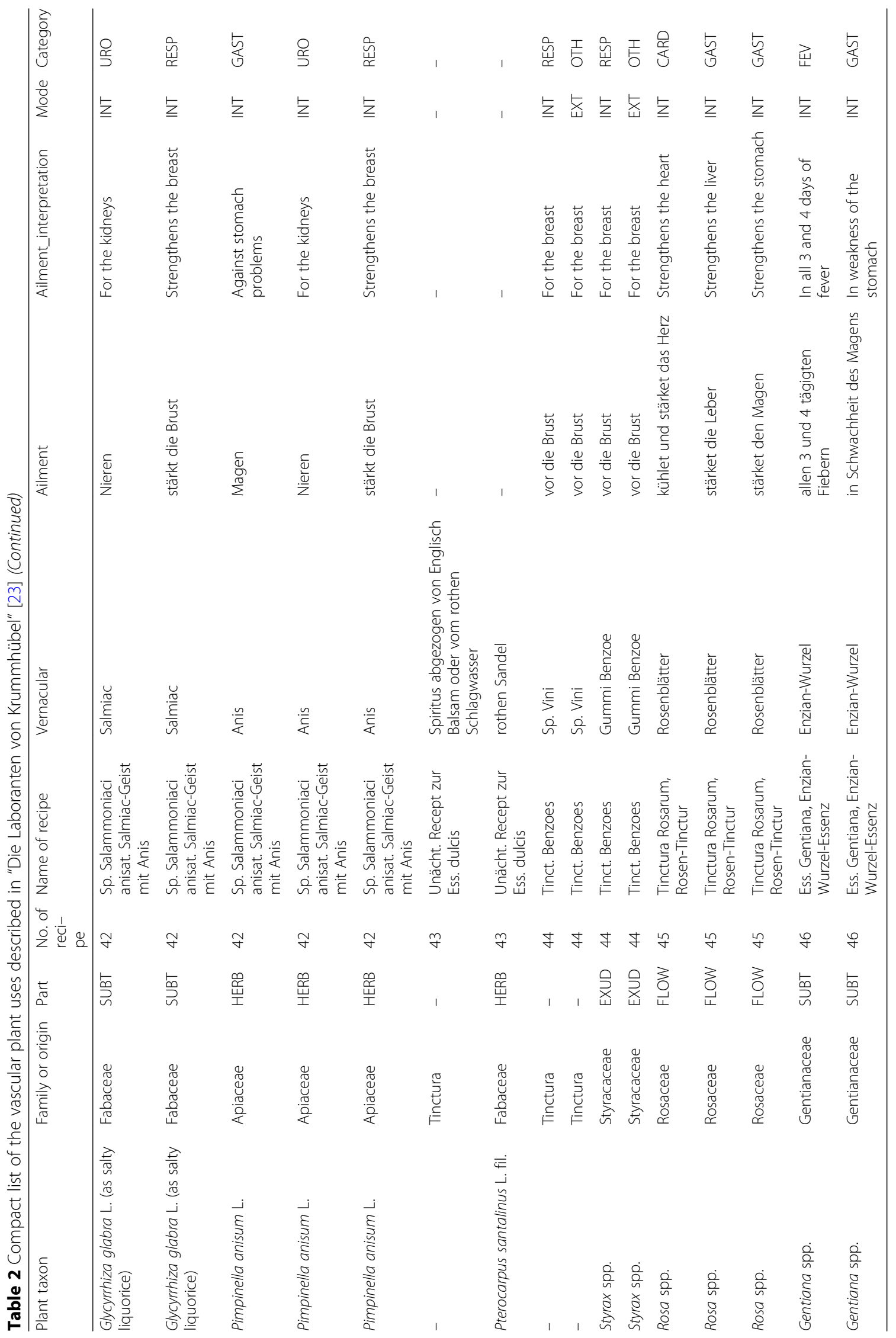


uterus; leishmaniasis and leucorrhea; anaemia; headaches; and snake bites. It is also used for its aphrodisiac, stimulant, anti-inflammatory, antiseptic, anti-tetanus, antirheumatic, antiherpetic, anthelminthic, anticancer, antitumour (prostate tumours) and antiparalytic properties ([63] and references cited herein). Many of these indications were also mentioned by Krummhübel herbalists and are recognised by modern medicine [74, 76, 77].

Guaiacum (Guaiacum officinale L.) is stated to possess antirheumatic, anti-inflammatory, diuretic, mild laxative and diaphoretic properties [74, 76, 77]. Traditionally, it has been used for subacute rheumatism, also in syphilitic and gouty affections, and specifically for chronic rheumatism and rheumatoid arthritis [75]. Additional medicinal uses mentioned by Krummhübel herbalists include the treatment of oedema and scabies as well as blood purification.

Myrrh is a sap-like substance (resin) that is released from cuts in the bark of trees belonging to the genus Commiphora. Myrrh has antimicrobial, astringent, carminative, expectorant, anticatarrhal, antiseptic and vulnerary properties. Traditionally, it has been used for aphthous ulcers, pharyngitis, respiratory catarrhs, common cold, furunculosis, wounds and abrasions, specifically for mouth ulcers, gingivitis and pharyngitis [75]. It is unknown which Commiphora species was used by Krummhübel herbalists, but they recommended it, among others, as a remedy for scurvy and plague as well as to stimulate appetite.

Crocus sativus L., commonly known as saffron, is used in folk medicine as an antispasmodic, eupeptic, gingival sedative, anticatarrhal, nerve sedative, carminative, diaphoretic, expectorant, stimulant, stomachic, aphrodisiac and emmenagogue. Furthermore, modern pharmacological studies have demonstrated that saffron extract or its active constituents have antitumor effects, radical scavenger properties and hypolipemic effects [75]. Krummhübel herbalists additionally used this plant in their medical mixtures as remedies for scurvy, any injuries and to support postpartum recovery.

Since time immemorial, people have tried to find medications to alleviate pain and to cure various diseases. In every period, every successive century from the development of humankind and advanced civilisations, the healing properties of certain medicinal plants were identified, recorded and passed on to successive generations. The benefits of one society were conveyed to another, which upgraded the old properties and discovered new ones, until the present days. The continuous and perpetual interest of people in medicinal plants has led to today's modern and sophisticated fashion of their processing and usage [69].

\section{Conclusions}

This paper presents a data mining approach and a survey of the herbal drugs contained in Reitzig. Our study revealed that many plants used in medical treatments by Krummhübel herbalists were also known in other regions between the sixteenth and twentieth centuries. The medicinal plants documented in all ethnobotanical studies considered include Angelica ssp., Carlina acaulis L., Gentiana spp., Juniperus spp., Rosa spp. and Veronica spp. However, eight, mainly exotic plants, were exclusive in therapeutic mixtures of Krummhübel herbalists. They encompass Copaifera officinalis L., Drimys winteri J.R. Forst. \& G. Forst., Hedysarum spp., Myristica fragrans Houtt., Piper longum L., Silene baccifera (L.) Roth and Syzygium aromaticum (L.) Merr. \& L.M. Perry. Although these taxa originate from various parts of the world, they were quite frequently used in several remedies by Krummhübel herbalists and are still important herbs in modern phytotherapy. Besides, the preserved recipes of Krummhübel herbalists also cover animal, fungus and mineral formulations and other organic and inorganic ones. Comparing such old data with contemporary herbal medicine and phytotherapy might enhance our understanding of modern practices and help to document the tradition of use, which is required for the regulatory approval of new herbal drugs. We showed that therapeutic effects of medicinal plants used by Krummhübel herbalists in traditional and modern medicine are mainly congruent, but there are also some novelties.

Currently, based on the achievements of Krummhübel herbalists, it seems to be important to attempt to reproduce therapeutic mixtures from the preserved recipes. This would provide an opportunity to learn more about the real effects of the former medicines and their therapeutic activities. The obtained data can also be used in the search for new drugs.

\section{Additional file}

Additional file 1: A full dataset of the recorded plant taxa, plant parts and other constituents used, as well as the therapeutic uses. (XLSX 37 kb)

\begin{abstract}
Acknowledgements
The authors wish to thank Mrs. Bożena Polak, M.Sc. (an academic teacher of the German language at the Wrocław University of Environmental and Life Sciences, Wrocław, Poland) for helping in translating some of the old German phrases. We also wish to thank Mrs. Anne Roestel (Deutsches ApothekenMuseum, Heidelberg, Germany) for helping in determining the composition and use of certain inorganic components of medicinal mixtures produced by Krummhübel herbalists. We thank the three anonymous reviewers for their careful reading of our manuscript and their insightful comments and suggestions to improve the quality of the final paper.
\end{abstract}

Funding

No funding was received for this research. 


\section{Availability of data and materials}

Data on the ethnobotanical/medical uses of plants are presented in this article in Table 1.

\section{Authors' contributions}

KS, IS and JP conceived and designed the study. JP and MP conducted the data collection and analysed the data. Literature retrieval was done by KS, IS and JP. KS, IS and JP drafted the manuscript. JP participated in the design and coordination. JP identified the plant species and reviewed the ethnobotanical literature. JP and MP revised the manuscript. All authors read and approved the final manuscript.

\section{Ethics approval and consent to participate}

Not applicable.

\section{Consent for publication}

Not applicable.

\section{Competing interests}

The authors declare that they have no competing interests.

\section{Publisher's Note}

Springer Nature remains neutral with regard to jurisdictional claims in published maps and institutional affiliations.

\section{Author details}

'Division of Botany, Institute of Biology, University of Opole, Oleska 22, 45-052 Opole, Poland. ²Department of Physiotherapy, Institute of Physiotherapy, Opole University of Technology, Prószkowska 76, 45-758 Opole, Poland. ${ }^{3}$ Museum of Natural History, University of Wrocław, Sienkiewicza 21, 50-335 Wrocław, Poland. ${ }^{4}$ Department of Plant Biology, Institute of Biology, Faculty of Biology and Animal Science, Wrocław University of Environmental and Life Sciences, Kożuchowska 5b, 51-631 Wrocław, Poland.

\section{Received: 12 September 2018 Accepted: 5 April 2019}

Published online: 23 May 2019

\section{References}

1. Schwenckfeld C. Stirpium \& Fossilium Silesiae Catalogus. Görlitz; 1600.

2. Drobnik J, Stebel A. Central European medicinal bryophytes in the 16thcentury work by Caspar Schwenckfeld, and their ethnopharmacological origin. J Ethnopharmacol. 2015;175:407-11.

3. Schwenckfeld C. Hirschbergischen warmen Bades in Schlesien, Neben einem allgemeinen Bericht von mineralischen Wassern und wild Bädern. Und kurtzem Verzeichniss derer Kräuter und Berg Arthen. Görlitz: Verlegung Georg Opitz/Buch; 1607.

4. Chidiac EJ, Kaddoum RN, Fuleihan SF. Mandragora: anesthetic of the ancients. Anesth Analg. 2012;115:1437-41.

5. Peschel W, Prieto JM, Karkour C, Williamson EM. Effect of provenance, plant part and processing on extract profiles from cultivated European Rhodiola rosea L. for medicinal use. Phytochemistry. 2013;86:92-102.

6. Kačániová M, Ďurechová D, Vuković N, Kántor A, Petrová J, Hleba L, et al, Antimicrobial activity of Drosera rotundifolia L. Sci Pap Anim Sci Biotechnol. 2015;47:366-9.

7. Baranyai $B$, Joosten $\mathrm{H}$. Biology, ecology, use, conservation and cultivation of round-leaved sundew (Drosera rotundifolia L.): a review. Mires Peat. 2016;18:1-28.

8. Alamgir ANM. Origin, definition, scope and area, subject matter, importance, and history of development of pharmacognosy. Ther Use Med Plants Their Extr Vol 1 Prog Drug Res. Cham: Springer; 2017. p. 19-60.

9. Helmstädter A, Staiger C. Traditional use of medicinal agents: a valid source of evidence. Drug Discov Today. 2014;19:4-7.

10. Staub PO, Casu L, Leonti M. Back to the roots: a quantitative survey of herbal drugs in Dioscorides' De Materia Medica (ex Matthioli, 1568). Phytomedicine. 2016;23:1043-52.

11. Matthioli PA. New Kreüterbuch: mit den allerschönsten und artlichsten Figuren aller Gewechss, dergleichen vormals in keiner Sprach nie an Tag kommen. Prag: Melantrich von Auentin und Valgriß; 1563.
12. Mattuschka de HG. Enumeratio stirpium in Silesia sponte crescentium. In usum Herborisantium. Vratislaviae: Sumptibus Guilielmi Theophili Kornii; 1779.

13. Kneipp S. Pflanzen-Atlas zu Seb. Kneipp's "Wasser-Kur", enthaltend die Beschreibung und naturgetreue bildliche Darstellung von sämtlichen in dem genannten Buche besprochenen, sowie noch einigen andren vom Volke vielgebrauchten Heil-Pflanzen. Kempten: J. Kasel Verlag; 1892.

14. Kujawska M, Łuczaj Ł, Sosnowska J, Klepacki P. Rośliny w wierzeniach i zwyczajach ludowych. Słownik Adama Fischera. Wrocław: Polskie Towarzystwo Ludoznawcze; 2016.

15. Madaus G. Lehrbuch der biologischen Heilmittel. Leipzig: Thieme; 1938.

16. Lardos A. Historical approaches in ethnopharmacology. In: Heinrich M, Jäger AK, editors. Ethnopharmacology. Singapore: Wiley; 2015. p. 333-41.

17. Herzig A, Ruchniewicz K, Ruchniewicz M. Śląsk i jego dzieje. Wrocław: Wydawnictwo Via Nova; 2012.

18. Herzig A. Geschichte Schlesiens: Vom Mittelalter bis zur Gegenwart. C.H. Beck Verlag: München; 2015

19. Troschel JE. Reise von Berlin über Breslau nach dem schlesischen Gebirge im Sommer 1783. Berlin: Druck von A. Mylius; 1783.

20. Anonymus. Über Warbrunn Und Altwasser, aus einem Briefe vom Monat Junius im J. 1799. Schlesische Prov. 1799:30:524-537.

21. Kern JU. Schlesiens' Sagen, Legenden und Geschichten. Über Warbrunn Und Altwasser, aus einem Briefe vom Monat Junius im J: Druck von C. H. Storch und Comp; 1867.

22. Regell P. Zur Geschichte der Laboranten. Der Wander im Riesengebirge. 1900;12:223-224.

23. Reitzig H. Die Laboranten von Krummhübel. Krummhübel; 1943.

24. Junker U. Die Laboranten in Krummhübel in Aufsätzen in der Zeitschrift Der Wanderer im Riesengebirge Bodnegg; 2015. Available from: http://jbc. jelenia-gora.pl/Content/16993/JEL_17957_2015_Die-Laboranten-in-Kr_ 17957_Laboranten_im_Wanderer_im_Riesengebirge.pdf.

25. Rittman JC. Medicin-Buch in Krummhübel. Krummhübel; 1792.

26. Anonymus. Beschreibung meiner Reise über das Gläzer und das Riesengebirg von Landeck bis Warmbrunn (Fortsetzung). Wiener Zeitschrift für Kunst, Lit Theater und Mode. 1828;140:1137-41.

27. Anonymus. Spaziergang durch das Hirschberger Thal. Morgenblatt für gebildete Les. 1840;1014-1015.

28. Donat F. Die Laboranten von Krummhübel. Der Wander im Riesengebirge. 1890;10:109.

29. Donat F. Die Laboranten von Krummhübel. II. Der Wander im Riesengebirge. 1890;11:112.

30. Hillebrand L. Die Krummhübler Wurzelmänner und Laboranten. Der Wander im Riesengebirge. 1931;9:130

31. Eberhardt W. Alt Krummhübel, ein Apothekendorf, Bunte Bilder aus dem Schlesierlande. Band 2. Schlesischen Pestalozzi-Verein: Breslau; 1903.

32. Winkler W. Flora des Riesen- und Isergebirges. Warmbrunn: Verlag und Druck von E. Gruhn; 1881.

33. Sudetenflora WW. Eine Auswahl charakteristischer Gebirgspflanzen. Dresden: Verlag C. Heinrich; 1900.

34. Staniaszek-Kik M, Żarnowiec J, Chmura D. The vascular plant colonization on decaying Picea abies logs in Karkonosze mountain forest belts: the effects of forest community type, cryptogam cover, log decomposition and forest management. Eur J For Res. 2016;135:1145-57 Available from: https://link. springer.com/article/10.1007/s10342-016-1001-8.

35. Łuczaj ŁJ. Plant identification credibility in ethnobotany: A closer look at Polish ethnographic studies. J Ethnobiol Ethnomed. 2010;6:36.

36. Strzelecka H, Kowalski J, editors. Encyklopedia zielarstwa i ziołolecznictwa. Warszawa: Wydawnictwo Naukowe PWN; 2000.

37. Anonymus. Wanderung nach Krummhübel. Zweiter Brief. Schlesische Prov. 1797:Band 25:509-18.

38. Wiater P. Witriolejnia i kopalnie pirytu w Szklarskiej Porębie Dolnej. Rocz Jeleniogórski Pismo Reg Karkonoszy. 2009;41:43-8 Available from: http://jbc. jelenia-gora.pl/Content/4618/rj_2009_m.pdf.

39. Schauenberg P, Paris F. Heilpflanzen. München-Bern-Wien: BLV Verlagsgesellschaft; 1975.

40. Anonymus. Riesengebirgs-Idyll. Neues Wiener Tagblat. 1924;313:2.

41. Müller T. Die Laboranten von Krummhübel. Das Kleine Volksblatt. 1944;194:9.

42. Wiater P. Laboranci w Górach Izerskich (cz. 2). 2017 [cited 2018 Mar 21]. Available from: http://www.goryizerskie.pl/ffile=art\&art_id=267\&page=1.

43. Wiater P. Laboranci w Górach Izerskich (cz. 3). 2017 [cited 2018 Mar 21]. Available from: http:/www.goryizerskie.pl/?file=art\&art_id=267\&page $=1$. 
44. Fontane T. Der letzte Laborant. Der Wander im Riesengebirge. 1931;9:132.

45. Bańkowski C, Kuźniewski E. Ziołolecznictwo ludowe. Warszawa-Wrocław: PWN; 1976.

46. von Uechtritz M. Botanische Bemerkungen. Flora oder Bot Zeitung. 1821;3: 33-48.

47. Spałek K, Spielvogel I. Zielarze z Karpacza. Panacea. 2014:42:32-4.

48. Spałek K, Spielvogel I. Tradycje fitoterapii w Karkonoszach. Sudety. 2015;157: 30-1.

49. Spałek K, Spielvogel I. Rośliny lecznicze i przyrodolecznictwo CieplicZdroju w opisie lekarza zdrojowego Caspara Schwenckfelda. Wiadomości Bot. 2017;61.

50. Eckstein F, Flamm S. Die Kneipp Kräuterkur. Bad Wörishofen: Gesundheitsverlag; 1933.

51. Laertes O. Die Heilkräuter nach Sebastian Kneipp. Wien: Verlag des Österreichischen Kneippbundes; 2002.

52. Heinrich M, Lardos A, Leonti M, Weckerle C, Willcox M. Best practice in research: Consensus Statement on Ethnopharmacological Field Studies ConSEFS. J Ethnopharmacol. 2018;211:329-39.

53. Tutin TG, Burges NA, Chater AO, Edmonson JR, Heywood VH, Moore DM, et al., editors. Flora Europaea I (2nd Edition) and Flora Europaea II-V. Cambridge: Cambridge University Press; 1993.

54. The Plant List. Version 1.1 online. 2013. Available from: http://www. theplantlist.org/ (accessed 1st January 2018).

55. Chase MW, Christenhusz MJM, Fay MF, Byng JW, Judd WS, Soltis DE, et al. An update of the Angiosperm Phylogeny Group classification for the orders and families of flowering plants: APG IV. Bot J Linn Soc. 2016;181:1-20.

56. Rohkam H. Vom Glasmacherdorf zum heilklimatischen Kurort. Breslau: Korn; 1939.

57. Kozlowska W, Wagner C, Moore EM, Matkowski A, Komarnytsky S. Botanical provenance of traditional medicines from Carpathian mountains at the Ukrainian-Polish border. Front Pharmacol. 2018;9:295.

58. Brinkhaus $B$, Lindner $M$, Schwenk M, Nagel M, Hentschel C, Kohnen R, et al. Phytobalneotherapie mit Graminis flos (Heublumen) versus Wärme-Bad. Perfusion. 2009;13:476-85.

59. Hentschel C, Brinkhaus B, Lindner M. Phytobalneotherapy using Flores Graminis - prospective study of the transdermal absorption of coumarin Focus Altern Complement Ther. 1997;2:189-90.

60. Maertens O. Die Heilkräuter nach Sebastian Kneipp. Leoben-Wien: Kneipp Verlag; 2003.

61. Spielvogel I, Spałek K. Medicinal plants used in pediatric prophylactic method of Sebastian Kneipp. Nat J. 2012;44:9-18.

62. Dal Cero M, Saller R, Weckerle CS. The use of the local flora in Switzerland: A comparison of past and recent medicinal plant knowledge. $J$ Ethnopharmacol. 2014;151:253-64.

63. da Trindade R, da Silva JK, Setzer WN. Copaifera of the Neotropics: A Review of the Phytochemistry and Pharmacology. Int J Mol Sci. 2018;19:1511.

64. Mittal M, Gupta N, Parashar P, Mehra V, Khatri M. Phytochemical evaluation and pharmacological activity of Syzygium aromaticum: A comprehensive review. Int J Pharm Pharm Sci. 2014;6:67-72

65. Da Rimino B. Cosarelle da me praticate et esperimentate. [Questo libro e di me Fra Bernardino da Rimino Sacerdote Capucino imprestato al Illustrissimo Signor Cavaliere Daniele Antonio Felice Cappelo e doppoi disse che il detto Signor Cavaliere se lo tenesse]. 1600.

66. Strocchia ST. The nun apothecaries of Renaissance Florence: Marketing medicines in the convent. Renaiss Stud. 2011:25:627-47.

67. Yarnell E, Abascal K. Dilemmas of traditional botanical research. Herb Gram. 2002;55:46-54

68. Harvey AL. Natural products in drug discovery. Drug Discov Today. 2008;13: 894-901.

69. Petrovska BB. Historical review of medicinal plants' usage. Pharmacogn Rev. 2012;6:1-5.

70. Fisher P, Ward A. Medicine in Europe: Complementary medicine in Europe. BMJ. 1994;309:107-11.

71. Lange D. In: Bogers RJ, Craker LE, Lange D, editors. International trade in medicinal and aromatic plants. Actors, volumes and commodities. Netherlands: Med Aromat Plants. Springer; 2006.

72. UN. International Merchandise Trade Statistics. UN COMTRADE Database. 2014 [cited 2019 Jan 2]. Available from: http://comtrade.un.org

73. Leonti M, Staub PO, Cabras S, Castellanos ME, Casu L. From cumulative cultural transmission to evidence-based medicine: Evolution of medicinal plant knowledge in Southern Italy. Front Pharmacol. 2015;6:207.
74. Urban B, Lepich C, Läger R. Kleines Wörterbuch der Pflanzenmedizin. Institut für Pharmakologie der Univerisität Wien. Wien: Schickmayr Werbung \& Produktion $\mathrm{GmbH} ; 2002$.

75. Ebadi M. Pharmacodynamic Basis of Herbal Medicine. 2nd Editio. Taylor \& Francis Group; 2006

76. Fintelmann V, Weiss RF. Lehrbuch Phytoterapie. Stuttgart: Hipokrates Verlag; 2009.

77. Quattrocchi U. CRC World Dictionary of Medicinal and Poisonous Plants: Common Names, Scientific Names, Eponyms, Synonyms, and Etymology. J. Chem. Inf. Model. London, New York: CRC Press Taylor \& Francis Group; 2012.

78. Akaberi M, Sobhani Z, Javadi B, Sahebkar A, Emami SA. Therapeutic effects of Aloe spp. in traditional and modern medicine: A review. Biomed Pharmacother. 2016;84:759-72.
Ready to submit your research? Choose BMC and benefit from:

- fast, convenient online submission

- thorough peer review by experienced researchers in your field

- rapid publication on acceptance

- support for research data, including large and complex data types

- gold Open Access which fosters wider collaboration and increased citations

- maximum visibility for your research: over $100 \mathrm{M}$ website views per year

At BMC, research is always in progress.

Learn more biomedcentral.com/submissions 